University of Nebraska - Lincoln

DigitalCommons@University of Nebraska - Lincoln

Faculty Publications, Department of Psychology

Psychology, Department of

1999

\title{
Potential Associations among Genetic Markers in the Serotonergic System and the Antisocial Alcoholism Subtype
}

\author{
E. M. Hill \\ S. F. Stoltenberg \\ University of Michigan-Ann Arbor, sstoltenberg2@unl.edu \\ M. Burmeister \\ University of Michigan-Ann Arbor, margit@umich.edu \\ M. Closser \\ University of Michigan-Ann Arbor \\ R. A. Zucker \\ University of Michigan-Ann Arbor, zuckerra@med.umich.edu
}

University of Detroit Mercy and University of Michigan-Ann Arbor, hillelm@udmercy.edu

Follow this and additional works at: https://digitalcommons.unl.edu/psychfacpub

Part of the Genetic Processes Commons, Genetics Commons, Psychology Commons, and the Substance Abuse and Addiction Commons

Hill, E. M.; Stoltenberg, S. F.; Burmeister, M.; Closser, M.; and Zucker, R. A., "Potential Associations among Genetic Markers in the Serotonergic System and the Antisocial Alcoholism Subtype" (1999). Faculty Publications, Department of Psychology. 1055.

https://digitalcommons.unl.edu/psychfacpub/1055

This Article is brought to you for free and open access by the Psychology, Department of at DigitalCommons@University of Nebraska - Lincoln. It has been accepted for inclusion in Faculty Publications, Department of Psychology by an authorized administrator of DigitalCommons@University of Nebraska - Lincoln. 
Published in Experimental and Clinical Psychopharmacology 7:2 (1999), pp. 103-121; doi: 10.1037/10641297.7.2.103

Copyright (C) 1999 American Psychological Association, Inc. Used by permission.

Submitted June 4, 1998; accepted July 8, 1998.

\title{
Potential Associations among Genetic Markers in the Serotonergic System and the Antisocial Alcoholism Subtype
}

\author{
E. M. Hill, ${ }^{1,2}$ S. F. Stoltenberg, ${ }^{2}$ M. Burmeister, ${ }^{3}$ M. Closser, ${ }^{3}$ \\ and R. A. Zucker ${ }^{4}$
}

1. University of Detroit Mercy, Detroit, Michigan, USA

2. Department of Psychiatry, University of Michigan, Ann Arbor, Michigan, USA

3. Department of Psychiatry and Mental Health Research Institute, University of Michigan, Ann Arbor, Michigan, USA

4. Departments of Psychiatry and Psychology, University of Michigan, Ann Arbor, Michigan, USA

Corresponding author - E. M. Hill, Department of Psychology, University of Detroit Mercy, 8200 West Outer Drive, Detroit, MI 48219, email hillelm@udmercy.edu

\begin{abstract}
Alcoholism is transmitted in families. The complexity and heterogeneity of this disorder has made it difficult to identify specific genetic correlates. One design with the potential to do so is the familybased association study, in which the frequencies of genetic polymorphisms are compared between affected and nonaffected members. Reduced central serotonin neurotransmission is associated with features of an antisocial subtype of alcoholism, although a primary deficit has not been traced to a particular component. Genetic markers related to the sertonergic system have been identified, located, and cloned. If associations can be discovered, the development process for pharmacotherapy could be facilitated. In this review, the evidence for the involvement of the serotonergic system in antisocial alcoholism is examined, and the potential for family-based association studies to identify specific components that may be involved is discussed.
\end{abstract}

Although the familial nature of alcoholism has been recognized for quite some time (Cotton, 1979; Goodwin, 1979), it is clear that the transmission of alcoholism across generations 
does not follow a simple monogenic Mendelian pattern (Stone \& Gottesman, 1993). Alcoholism is one of many complex traits whose complicated patterns of inheritance make it very difficult for geneticists to identify specific mechanisms that may confer vulnerability (Lander \& Schork, 1994). An important step in the genetic dissection of alcoholism will be to define the phenotype restrictively, thereby decreasing the likelihood that variation among types of alcoholism (each with potentially different genetic correlates) will obscure patterns that may be seen when a more homogeneous sample is tested (Lander \& Schork, 1994).

Given that familial patterns of alcoholism are complex, it may be desirable to use a method of genetic analysis that does not directly rely on inheritance patterns. Association studies allow one to ask whether a certain allele occurs at a higher frequency in affected individuals than it does in unaffected individuals in a population. Therefore, in association studies, in contrast to linkage studies, family history data are not usually collected. If a certain allele at a candidate gene locus occurs more frequently in the affected individuals than it does in the controls, it suggests that the particular allele plays a role in the phenotype of interest (Lander \& Schork, 1994). In linkage studies, models of transmission are fitted to family pedigrees containing the trait of interest, and the mode of inheritance needs to be specified, but nothing need be known about specific genetic correlates of the trait. On the other hand, in association studies, nothing need be known about the mode of inheritance, but specific candidate genes need to be identified (Lander \& Schork, 1994). Recent advances in understanding the phenotype of alcoholism and in molecular genetics of the serotonergic system have made such association studies feasible for alcoholism.

In this article, we review an approach to defining the phenotype that may result in a clearer understanding of the genetic basis of alcoholism than is currently available. We examine the potential role of the serotonergic system in one type of alcoholism by first examining some of the evidence for a genetic basis for alcoholism. Next, we review some of the evidence for a homogeneous subtype of alcoholism, which should enable researchers to define alcoholism phenotypes better, which in turn will make detailed genetic analysis possible. We then review the evidence for an association between the serotonergic system and antisocial alcoholism and discuss the potential for association studies (i.e., candidate gene analysis) with respect to components of the serotonergic system and antisocial alcoholism. Finally, we address the issue of pharmacologic intervention targeted at the serotonergic system that might result in the development of a more effective treatment for alcoholism. In this article, alcoholism refers to the psychiatric disorder of alcohol dependence. Specific symptoms and subtypes within this heterogeneous disorder are discussed as relevant.

\section{Genetic Basis of Alcoholism}

It has long been recognized that the occurrence of alcoholism (alcohol abuse or dependence) is clustered within families. However, the majority of offspring of alcohol-dependent parents do not develop similar problems with alcohol, and only about one third develop alcohol dependence (Cotton, 1979; Goodwin, 1979). It has been very difficult to identify precise biological mechanisms that are associated with familial alcoholism. Candidates have ranged from physiological or psychological responses to alcohol (Schuckit, 1980) to 
differences in temperamental characteristics, such as emotionality or sociability (Tarter, Alterman, \& Edwards, 1985). More direct evidence that alcoholism has a specific genetic basis comes from three research areas: twin studies, adoption studies, and genetic marker studies of association and linkage (Devor \& Cloninger, 1989; McGue, 1994; Merikangas, 1990). However, results from twin studies are difficult to generalize; virtually all of the adoption studies have been highly criticized for cursory specification of possible environmental or intrauterine influences, diagnostic criteria, and statistical analyses (Littrell, 1988; Searles, 1988; Zucker, 1987); moreover, recent linkage studies are not consistent (Long et al., 1998; Reich et al., 1998). In general, twin studies show a higher alcoholism concordance in monozygotic than dizygotic twins (beginning with Kaij, 1960), and adoption studies show a larger influence of biological parents than adoptive parents (beginning with Cloninger, Bohman, \& Sigvardsson, 1981).

According to recent twin studies, the genetic effect on drinking behavior may vary with gender, cohort, and type of measure (i.e., alcohol consumption or alcohol dependence; Kendler, Heath, Neale, Kessler, \& Eaves, 1992; Kendler, Neale, Heath, Kessler, \& Eaves, 1994; Pickens et al., 1991). Heritability estimates also vary by age cohort (Prescott, Hewitt, Heath, Truett, Neale, \& Eaves, 1994; Prescott, Hewitt, Truett, Heath, Neale, \& Eaves, 1994). Separating alcohol dependence from abuse and males from females revealed the following consistencies (McGue, 1994): Alcohol dependence has a moderate additive genetic influence for men $(40 \%-60 \%)$ and a modest influence for women $(0 \%-58 \%)$. Both are affected by environmental factors. McGue concluded, however, that alcohol abuse (without dependence) shares genetic influences with conduct disorder and other expressions of behavioral undercontrol, which may derive from an inability to inhibit behavior.

Despite such high heritability estimates, it has been difficult to isolate specific genetic factors associated with alcoholism. Studies with genetic markers began 10 years ago. The first exciting results, which suggested that a major gene was linked or associated with alcoholism, were studies with protein polymorphisms (S. Y. Hill, Aston, \& Rabin, 1988; Tanna, Wilson, Winokur, \& Elston, 1988) and a DNA polymorphism of a dopamine receptor (Blum et al., 1990). Subsequent results have been inconsistent, however. Many associations between alcoholism and protein polymorphisms have been reported but not replicated (e.g., Clemente, Fananas, Moral, \& Sanchez-Turet, 1994; E. M. Hill, Wilson, Elston, \& Winokur, 1988; S. Y. Hill et al., 1988; Tanna et al., 1988; Wesner et al., 1991). The initial report of association with the DRD2 marker (Blum et al., 1990) was followed by conflicting studies. These inconsistent results have been attributed to several possibilities; among them are the following: (a) Ethnicity was not matched in the affected and control samples, and (b) the A1 allele has a nonspecific relationship to many neuropsychiatric disorders (Gelernter, Goldman, \& Risch, 1993; McGue, 1994; Pato, Macciardi, Pato, Verga, \& Kennedy, 1993). A definitive analysis has recently been conducted, and it found no evidence for association of the A1 allele with alcoholism (Edenberg et al., 1998).

The biological basis of vulnerability to alcoholism may eventually be clarified by two major long-term efforts of broad scope. One is the Collaborative Study on the Genetics of Alcoholism (COGA; Reich et al., 1998), and the other is an effort at the National Institute on Alcohol Abuse and Alcoholism Laboratory of Neurogenetics (NIAAA LN; Long et al., 1998). The COGA study includes a multidimensional assessment for segregation and 
linkage analyses. The NIAAA LN is conducting association and linkage studies using populations that are genetic isolates. Both groups have published genome-wide linkage analyses of an alcohol dependence phenotype (Long et al., 1998; Reich et al., 1998). Results have not been consistent, however. Both groups found significant linkage between locations on chromosome $4 \mathrm{q}$ and the absence of alcohol dependence, which suggests a protective effect of the nearby genes related to alcohol metabolism (i.e., alcohol dehydrogenase and aldehyde dehydrogenase). Faster alcohol metabolism might lower tolerance by causing aversive flushing (Chen et al., 1996). Other linkage findings were not consistent, however. Significant locations on chromosomes 1 and 7 were found in the COGA study (Reich et al., 1998), whereas a site on chromosome 11 showed linkage in the NIAAA LN study with an American Indian tribe (Long et al., 1998). Plausible candidate genes for alcohol dependence are located near these sites, including genes for neurotransmitter receptors (DRD4, a dopamine receptor, and GABARB1, a $\gamma$-aminobutyric acid receptor) and enzymes involved in neurotransmitter synthesis (tyrosine hydroxylase and tryptophan hydroxylase).

In addition, the COGA study assessed a specific phenotype, the P3 event-related brain potential (Begleiter et al., 1998). For people with a variety of disorders, including alcoholism, schizophrenia, and attention deficit disorder, P3 voltage is lower than normal when they must attend to difficult visual tasks in an experiment (reviewed by Begleiter et al., 1998). Significant linkage was found between $P 3$ amplitude and locations on chromosomes 2 and 6; suggestive linkage evidence was found for locations on chromosomes 5 and 13 (Begleiter et al., 1998). These locations do not overlap with linkage findings from the two studies of alcohol dependence. Future research should clarify the discrepancies in these findings, which could have been the result of differences in sampling and choice of phenotype for analysis. Achieving consistency and replicability of findings may require the use of very specific phenotypes. Future research must be bolstered by recent advances in our understanding of the phenotypic heterogeneity of alcoholism combined with current advances in molecular genetics. Below, we review pertinent research for both of these areas.

Familial transmission of alcoholism has been clearly documented. The genetic determinants are extremely complex, however. Different genes may influence different aspects of alcohol consumption, preference, and dependence; furthermore, these genes may be expressed at different developmental stages, and there is some evidence of different genetic mechanisms in men and women. Environmental effects on people of varying initial risk at various life span stages are difficult to demonstrate without clear markers of initial risk and clear environmental situations that are specifically tied to alcoholism. Behavior genetics studies usually produce moderate heritability estimates for alcoholism (but tell nothing about which genes or environmental factors are critical), and proposed genetic linkages and associations are repeatedly unreplicated. Alcoholism needs to be treated as a complex trait with potential complications of incomplete penetrance, phenocopies, heterogeneity, or polygenic inheritance (cf. Lander \& Schork, 1994). It appears that alcoholism, inclusively defined, will not be amenable to a search for single-gene effects; it probably is polygenic and heterogeneous. In reviewing the genetics literature, Stone and Gottesman (1993) concluded that the most reasonable model of alcoholism is a multifactorial-polygenic one. Schuckit (1994) elaborated on the role of reduced responsiveness to alcohol as a risk factor for alcoholism within a context of a multifactorial model with potentially polygenic genetic 
effects. In addition to focusing on polygenic models, however, other researchers are testing highly homogeneous subgroups with specific risks and problems to look for single important genes. There may be fewer genes involved if specific features can be examined. Geneticists are using methods to narrow the definition of a disease to isolate homogeneous subgroups that are more likely to show Mendelian inheritance (Lander \& Schork, 1994; McGuffin, Owen, O’Donovan, Thapar, \& Gottesman, 1994). Four criteria have been useful in medical genetics: age at onset, family history, severity, and clinical phenotype (Lander \& Schork, 1994). Our article applies these criteria to alcoholism. The linkage and association studies noted above treated alcoholism as a single disorder; thus, their relevance is unclear. Newer approaches attempt to define subtypes within the heterogeneous disorder of alcoholism.

\section{Homogeneous Subtypes of the Heterogeneous Alcoholism Phenotype}

From both phenomenological and developmental perspectives, one subtype of alcoholism has gained acceptance; the predominant characteristics of this subtype, called antisocial alcoholism (AAL), are impulsive, aggressive traits (Zucker, 1987). Other subtypes are less well defined. Some investigators have suggested that there are several types embedded within the substantially more heterogeneous, nonantisocial alcoholic population (Zucker, 1994). One that has moderate consensus is a subtype in which depression and anxiety precede development of dependence; it has been labeled negative affect alcoholism (NAAL; Babor et al., 1992; Cloninger et al., 1981; Zucker, 1987). These two subtypes appear to be consistent with preclinical conditions that are differentiable among adolescents and that correlate with two major pathways for developing alcohol problems (i.e., an externalizing or behavioral undercontrol pathway versus an internalizing pathway). Sher $(1991,1994)$ described several pathways to alcoholism, notably a deviance proneness pathway, a negative affect pathway, and an enhanced reinforcement pathway. The negative affect pathway appears to involve childhood internalizing symptomatology that-only in adulthood-may develop into alcohol dependence. Women with alcoholism are more likely to show this pattern than the AAL pattern (discussed further below; Schuckit, Pitts, Reich, King, \& Winokur, 1969). The typology proposed by Babor et al. (1992) was based on cluster analyses of clinical characteristics. In this conceptualization, types differed on premorbid risk, age of onset, dependence severity, alcohol-related problems, chronicity, negative consequences, and comorbidity. E. O. Johnson, van den Bree, and Pickens (1996a) created symptom scales ("environmental" and "genetic") that were based on differential concordance between monozygotic and dizygotic twins. Using cluster analysis of the scales with a sample of alcoholic males, they identified three subtypes: mild, severe, and dyssocial (E. O. Johnson, van den Bree, \& Pickens, 1996b).

AAL has been identified in multiple classifications (Babor et al., 1992; Cloninger et al., 1981; Hesselbrock et al., 1984; Zucker, Ellis, \& Fitzgerald, 1994). The hallmark characteristics found in various populations are early age of onset, dense family history of alcoholism, greater expressivity among family members, and characteristics of adult antisocial personality disorder and childhood conduct disorder (Zucker, 1994; Zucker, Ellis, Fitzgerald, \& Bingham, 1996). E. O. Johnson, van den Bree, and Pickens (1996b) found similar symptoms 
in two of their subtypes (severe and dyssocial). High frequency of other drug problems also appears to be characteristic of a subtype with antisocial traits (Helzer, Burnam, \& McEvoy, 1991). Early elements of the AAL subtype can be differentiated even among adolescents as conduct disorder symptoms (Weber, Graham, Hansen, Flay, \& Johnson, 1989; Donovan \& Jessor, 1985). Antisocial personality may be a very useful characteristic in subtyping for clinical treatment (Litt, Babor, Del Boca, Kadden, \& Cooney, 1992). Meyer (1994) concluded that the AALs were a homogeneous subtype, with early age of onset of alcohol problems and antisocial behavior preceded by a history of childhood conduct disorder. Furthermore, there is evidence for significant additive genetic variance for an early age of onset subtype (McGue, Pickens, \& Svikis, 1992).

NAAL (Zucker, 1987) involves depression and anxiety disorders that precede the development of alcohol problems. Longitudinal studies show such a progression in a subset of alcoholics (Jones, 1971). Internalizing problems and negative affect are more prevalent among children and adolescents who have alcoholic parents (reviewed by Sher, 1991). Indeed, there may be some common genetic influence on major depression and alcoholism (Kendler, Heath, Neale, Kessel, \& Eaves, 1993; Merikangas, Leckman, Prusoff, Pauls, \& Weissman, 1985). Some anxiety disorders frequently precede alcoholism, specifically the cognitive anxiety disorders (e.g., agoraphobia or social phobia), but alcoholism generally precedes the development of other anxiety disorders such as panic disorder (Kushner, Sher, \& Beitman, 1990; but see also a contrary argument in Schuckit \& Hesselbrock, 1994).

Researchers investigating the prominent alcoholism typologies consistently propose gender differences in environmental influences and in comorbidity of anxiety and depression with alcohol dependence (Babor et al., 1992; Cloninger, 1987a; Zucker, 1987). Women's alcoholism is typically viewed as being secondary to other disorders, which classifies most alcoholic women into the NAAL subtype. However, the interrelationships of gender, comorbidity, and family history risk are not yet clear (Del Boca, 1994). Reports of comorbidity in alcoholic women do indicate more prevalent comorbid disorders than for alcoholic men (Hesselbrock, Meyer, \& Keener, 1985; Nunes, Quitkin, \& Berman, 1988). Clinical studies of subtypes have shown a lower prevalence of AAL among women (men 50:50 and women 60:40, type NAAL vs. AAL; Babor et al., 1992), but Del Boca concluded that the phenomenology and risk factors for AAL were similar for men and for the subgroup of women in which it occurred. In a sample of women convicted for drunk driving, antisocial traits were tightly associated with early-onset alcoholism and a dense family history (Lex, Goldberg, Mendelson, Lawler, \& Bower, 1994). Zucker and Gomberg (1995) noted that alcoholism is tied to antisociality more tightly in women than in men. Alcohol problems are increasing among younger cohorts of women. In national surveys, one clear trend is a decreased age at onset of alcohol consumption by young women (Clayton, Voss, Robbins, \& Skinner, 1986), and heavy drinking by young women may be more common now than in previous decades (Fillmore, 1984). Evidence also suggests that alcohol-related motor vehicle crashes among young women have increased over the last decade (Popkin, Kannenberg, Lacey, \& Waller, 1988). In the past, cultural sanctions against drinking by women may have masked the role of biological susceptibility in patterns of alcoholism. Thus, efforts to study the AAL subtype in women are warranted. 
The AAL subtype shows a stronger transmission pattern than alcoholism broadly defined. As a rough estimate, approximately $20 \%$ of men and $5 \%$ of women in the general population meet criteria for alcohol abuse (Reich \& Cloninger, 1990). First-degree relatives of alcoholics have a two- or three-fold greater risk of alcoholism (about $45 \%$ for male relatives, $15 \%$ for female relatives) than relatives of nonalcoholics (Reich \& Cloninger, 1990). Estimates from Guze, Cloninger, Martin, and Clayton (1986) were similar; they found the risk for male relatives of alcoholics to be $27.2 \%$, compared with $16.8 \%$ for male relatives of nonalcoholics (figures for women: relatives of alcoholics, $6.1 \%$ vs. relatives of nonalcoholics, 2.3\%). Although the AAL subtype is less prevalent (about one fourth to one third of alcoholics), family transmission is stronger. The original studies (reviewed in Cloninger, 1987a) gave relative risks for men from NAAL fathers of about 2 to 1 ( $9 \%$ vs. $4 \%$ ), compared with relative risks of 6.9 for those with AAL fathers (about 2.5\% vs. 17.2\%). Whereas Cloninger's (1987b) typology and the specific adoption studies providing evidence for it have been heavily criticized (Searles \& Alterman, 1994), there has been little argument that alcoholics with the defining criteria (early onset and antisocial traits) also come from families more densely loaded with alcoholism vulnerability. Thus, AAL is a promising subtype for genetic analysis, meeting Lander and Schork's (1994) criteria of early age at onset, dense family history, and restricted phenotype.

\section{Relationship of Specific Features of AAL to Serotonin}

There are hallmark features of the AAL subtype that are related to biochemical findings. We will focus on impulsivity, a dimension that may underlie the manifestations of alcoholism, antisociality, and aggression that characterize people with AAL. McGue (1994) considered behavioral undercontrol disorders to be the basis of genetic influences on male alcohol abuse. Behavioral undercontrol is related to impulsiveness and aggression. The serotonin system has a clear relationship to impulsivity. In Virkkunen and Linnoila's (1993) model of serotonin effects on drinking, they specified a relationship between serotonin and impulsivity that may lead to drinking, which may in turn lead to release of previously inhibited aggression. Sher (1994) cautioned, however, that links between impulsivity and drinking are not proven; rather, he suggested the related construct of coping skills or problem solving to be a more general deficit among alcoholics. The most accepted model of the role of intoxication in releasing aggression is disinhibition (Bushman \& Cooper, 1990; Graham, 1980). According to this model, the effect of alcohol probably operates by reducing fear and decreasing cognitive ability to plan (Pihl, Peterson, \& Lau, 1993). In Cloninger's far-reaching biosocial model of personality, the serotonin system is related to a harm avoidance dimension (Cloninger, 1986,1987a, 1987b). Cloninger's (1987b) definition of harm avoidance was "a heritable tendency to respond intensely to signals of aversive stimuli, thereby learning to inhibit behavior to avoid punishment, novelty, and frustrative nonreward" (p. 575). He characterized the antisocial personality type (Type II alcoholic) as having the following traits: high novelty seeking, low harm avoidance, and low reward dependence. The combination of high novelty seeking and low harm avoidance was hypothesized to be common to the "impulsive-aggressive" personality cluster. Our 
conceptualization is also that a salient feature of AAL is impulsivity, which may be synonymous with low harm avoidance.

This interpretation basically fits the model presented by Benkelfat (1993), who depicted serotonin as affecting behavioral modulation in general, where the result of low serotonin level varies depending on the behavioral dimension that is activated at a particular time (p. 54). For example, regarding the dimension of consummatory behavior, the typical output is feeding, but the output when serotonin levels are low is hyperphagia. For aggressive behavior, the output is hostility or fighting, which is potentiated when serotonin is low. In a similar manner, in the context of reward, the dimension of operant behavior has an output of self-stimulation, which may be facilitated by low serotonin. Siever and Trestman (1993) viewed low serotonin effects as a release from suppression of punished behavior (i.e., impulsivity). Jacob and Fornal (1994) conceptualized serotonin's actions similarly, as modulating and integrating both motor output and sensory input. Disruption of this function could result in abnormal reactivity to stimuli as well as inappropriate repetitive behaviors (e.g., consumption or aggression). Anton (1996) presented a model of the neural basis of various facets of alcoholism in which he postulated that serotonin plays a role in "craving," obsessional thinking, and compulsive use, in contrast with other facets of alcoholism that are subserved by dopamine (sensitization), endorphin-enkaphalin (reward sensation), or norepinephrine and $\gamma$-aminobutyric acid (stress reduction; p. 44). Compulsive use is within the realm of the dimension we focused on in AAL - behavioral undercontrol and impulsivity.

\section{Serotonergic Neurotransmission in AAL}

LeMarquand, Pihl, and Benkelfat (1994a, 1994b) recently reviewed the relevant evidence for a role of serotonergic neurotransmission in alcohol intake, abuse, and dependence. The potential involvement of components of the serotonin system is shown in Table 1. In this table, we note the existence and type of evidence relating to deficits in particular components. If more than two studies support a relationship, these are given in the text rather than tabulated (i.e., "see text"). Receptors are described using the nomenclature established in 1993 by the Serotonin Club Receptor Nomenclature Committee (Humphrey, Hartig, \& Hoyer, 1993). There is conflicting evidence in many areas because of small sample sizes and the use of differing methodologies. The information in Table 1 is presented for heuristic purposes, and it indicates whether evidence exists from animal and human experimental studies for an association of a change in a component with alcohol consumption or alcoholism. Studies of genetic polymorphism or deletions are described and tabulated later. Results from clinical trials with alcoholic patients are also discussed and tabulated in a later section. Experimental studies are described for rodents, nonhuman primates, and then humans. 
Table 1. Potential Involvement of Serotonergic Neurotransmission in Antisocial Alcoholism

\begin{tabular}{|c|c|c|c|}
\hline Component & Functional relationship & Sample & Reference \\
\hline \multicolumn{4}{|l|}{ Synthesis } \\
\hline Tryptophan hydroxylase & See Table 2 & & See Table 2 \\
\hline Serotonin level & $\begin{array}{l}\text { Lower level assoc. } \\
\mathrm{w} / \text { consumption }\end{array}$ & Rodents & See text \\
\hline \multicolumn{4}{|l|}{ Metabolism } \\
\hline \multirow[t]{8}{*}{ 5-HIAA } & $\begin{array}{l}\text { Lower levels assoc. } \\
\text { w/ alcohol consumption }\end{array}$ & Rhesus macaques & Higley et al., 1996a \\
\hline & $\begin{array}{l}\text { Lower levels assoc. } \\
\text { w/ lower social dominance }\end{array}$ & Rhesus macaques & Higley etal., 1996b \\
\hline & $\begin{array}{l}\text { Lower levels assoc. w/ } \\
\text { impulsivity and aggression }\end{array}$ & Rhesus macaques & Mehlman et al., 1994 \\
\hline & $\begin{array}{l}\text { Lower level in groups } \\
\text { with AAL }\end{array}$ & Multiple groups & See text \\
\hline & $\begin{array}{l}\text { Lower levels assoc. } \\
\text { w/ aggression }\end{array}$ & $\begin{array}{l}\text { Obs.-comp. } \\
\text { patients }\end{array}$ & Insel et al., 1990 \\
\hline & $\begin{array}{l}\text { Lower levels assoc. } \\
\text { w/ suicidality }\end{array}$ & Alc.-dep. patients & Roy et al., 1990 \\
\hline & $\begin{array}{l}\text { Lower levels assoc. } \\
\text { w/ impulsivity }\end{array}$ & $\begin{array}{l}\text { Alc.-dep. viol. } \\
\text { offenders }\end{array}$ & Virkkunen et al., 1994 \\
\hline & $\begin{array}{l}\text { Lower levels assoc. } \\
\text { w/ family history of AAL }\end{array}$ & Viol, offenders & Virkkunen et al., 1996 \\
\hline \multicolumn{4}{|l|}{ Activity } \\
\hline \multicolumn{4}{|l|}{ Autoreceptors } \\
\hline \multirow[t]{3}{*}{$1 \mathrm{~A}$} & $\begin{array}{l}\text { Higher density of receptors } \\
\text { in cortex }\end{array}$ & $P$ rats & See text \\
\hline & $\begin{array}{l}\text { Antagonists reduce alcohol } \\
\text { drinking }\end{array}$ & $P$ rats & Zhou et al., 1998 \\
\hline & Agonists block aggression & Male mice & Sanchez et al., 1993 \\
\hline 1B (alias 5-HT1D $\beta)$ & See Table 2 & & See Table 2 \\
\hline $1 \mathrm{E}, 1 \mathrm{~F}$ & No evidence of relationship & & No studies \\
\hline \multicolumn{4}{|l|}{ Postsynaptic receptors } \\
\hline \multirow[t]{4}{*}{ 2A (alias 5- $\left.\mathrm{HT}_{2}\right)$} & $\begin{array}{l}\text { Lower receptor density } \\
\text { in brain }\end{array}$ & $P$ rats & McBride et al., 1993 \\
\hline & $\begin{array}{l}\text { Mixed results of antagonist } \\
\text { on consumption }\end{array}$ & Rodents & See text \\
\hline & Reduced binding in platelets & $\begin{array}{l}\text { Violent adol. } \\
\text { patients }\end{array}$ & $\begin{array}{l}\text { Blumensohn et al., } \\
1995\end{array}$ \\
\hline & $\begin{array}{l}\text { Antagonist ritanserin had } \\
\text { no effect on intoxication }\end{array}$ & Healthy volunteers & Estevez et al., 1995 \\
\hline $2 B$ & No evidence of relationship & & No studies \\
\hline 2C (formerly 5-HTic) & $\begin{array}{l}\text { Responses blunted among } \\
\text { alcoholics especially AAL for } \\
\text { agonists MK-212 and } m \text {-CPP }\end{array}$ & Alc.-dep. patients & $\begin{array}{l}\text { Handelsman et al., } \\
1996 \\
\text { George et al., } 1997\end{array}$ \\
\hline \multirow[t]{2}{*}{3} & $\begin{array}{l}\text { Antagonists fail to reduce } \\
\text { ethanal self-admin. }\end{array}$ & Long-Evans rats & Beardsley et al., 1994 \\
\hline & $\begin{array}{l}\text { Antagonist ondonsetron } \\
\text { increased subjective } \\
\text { intoxication }\end{array}$ & Healthy volunteers & Swift et al., 1996 \\
\hline 4 & $\begin{array}{l}\text { Antagonist GR } 113808 \text { reduces } \\
\text { ethanol self-admin. }\end{array}$ & $P$ rats & Panocka et al., 1995 \\
\hline $5 \mathrm{~A}, 5 \mathrm{~B}, 6,7$ & No evidence of relationship & & No studies available \\
\hline
\end{tabular}




\begin{tabular}{|c|c|c|c|}
\hline \multicolumn{4}{|l|}{ Table 1. continued } \\
\hline Component & Functional relationship & Sample & Reference \\
\hline \multicolumn{4}{|l|}{ Reuptake } \\
\hline \multirow[t]{4}{*}{ Serotonin transporter } & $\begin{array}{l}\text { Uptake inhibitors decrease } \\
\text { drinking }\end{array}$ & Rodents & See text \\
\hline & $\begin{array}{l}\text { Uptake higher in alcoholics } \\
\text { and their adult children }\end{array}$ & Alcoholic patients & See text \\
\hline & $\begin{array}{l}\text { Platelet imipramine binding } \\
\text { correlated with hostility }\end{array}$ & Mixed patients & Same et al., 1995 \\
\hline & $\begin{array}{l}\text { More platelet transporter sites } \\
\text { in aggressive group }\end{array}$ & Pers. dis. patients & Coccaro et al., 1996 \\
\hline Transporter promoter & See Table 2 & & \\
\hline \multicolumn{4}{|l|}{ Metabolism } \\
\hline Monoamine oxidase A & See Table 2 & & See Table 2 \\
\hline Monoamine oxidase B & $\begin{array}{l}\text { Low platelet activity assoc. } \\
\text { w/ AAL subtype }\end{array}$ & Alcoholic patients & See text \\
\hline
\end{tabular}

Note: Assoc. $=$ associated, admin.$=$ administration, $\mathrm{AAL}=$ antisocial alcoholism, alc - -dep.$=$ alcohol-dependent, obs.-comp. = obsessive-compulsive, viol. $=$ violent, $\mathrm{P}=$ alcohol-preferring, adol. $=$ adolescent, pers. dis. $=$ personality disorder

There is a large body of animal and experimental literature suggesting that increases and decreases in serotonin function inversely affect ethanol consumption (LeMarquand et al., 1994b). There is more support for the proposal that increases in serotonin (5-HT) transmission are associated with decreases in intake of ethanol but less support for the converse, that decreased 5-HT leads to increased drinking (LeMarquand et al., 1994b). In this section, we will discuss relevant animal research and then describe human studies. In animals, ethanol intake has been shown to decrease after administration of 5-HT precursors, 5-HT uptake inhibitors, intracerebral 5-HT, and postsynaptic 5-HT agonists (Naranjo \& Bremner, 1993).

Strains of alcohol-preferring rats $(\mathrm{P}$; nonpreferring $=\mathrm{NP})$ showed lower central 5-HT; this finding was true for both the P strain (J. M. Murphy, McBride, Lumeng, \& Li, 1982) and fawn-hooded rats (Rezvani, Overstreet, \& Janowsky, 1990). In $F_{2}$ generation rats of $\mathrm{P} \times \mathrm{NP}$ intercrosses, both 5-HT and its metabolite, 5-hydroxyindoleaceticacid (5-HLAA), were lower in the nucleus accumbens of high-intake than in low-intake animals, confirming an association between alcohol-drinking behavior and the serotonin system in the $\mathrm{P}$ and NP strains (McBride, Bodart, Lumeng, \& Li, 1995). There is some evidence that P rats differ in 5-HT transporter function, as reflected by imipramine binding and serotonin uptake (Aurora, Tong, Jackman, Staff, \& Meltzer, 1983). Selective serotonin reuptake inhibitors (SSRIs) also affect the transporter, and they clearly decrease drinking in P rats (J. M. Murphy et al., 1988; Rezvani et al., 1990). Furthermore, in P strains of rats, high alcohol-

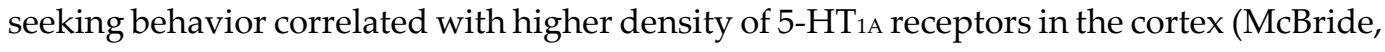
Guan, Chernet, Lumeng, \& Li, 1994; Wong, Reid, Li, \& Lumeng, 1993; Wong, Threlkeld, Lumeng, \& Li, 1990). Selectively blocking 5-HT1A receptor activity caused significant reduction in alcohol consumption by P rats, and combined SSRI and antagonist treatment reduced drinking further (Zhou, McKinzie, Patel, Lumeng, \& Li, 1998). A recent study with 
$\mathrm{P}$ rats showed reduction of alcohol intake after treatment with a 5-HT4 antagonist (Panocka, Ciccocioppo, Polidori, Pompei, \& Massi, 1995).

The specific 5-HT receptor subtypes appear to have a role in rodents' aggressive behavior, along with their role in alcohol consumption (Sanchez, Amt, Hyttel, \& Moltzen, 1993). The co-occurrence of serotonergic effects on alcohol consumption and aggression will be noted below in studies with nonhuman primates and humans. Both behavior patterns may be affected by alterations in the general dimension of impulsivity, as described earlier.

A program of research with primates has begun at the National Institutes of Health; this program is using rhesus macaques as a model of aggression, alcohol consumption, and impulse control (Mehlman et al., 1994). Cerebrospinal fluid (CSF) 5-HIAA has been inversely correlated with instances of intense aggression and with an operational measure of impulsive risk taking (e.g., comparatively long leaps through forest canopy; Mehlman et al., 1994). A confirmatory study from another laboratory showed individual differences among male cynomolgus monkeys (also macaques) in hormonal response to fenfluramine; monkeys with blunted response showed more aggressive behavior (Keyes, Botchin, Kaplan, Manuck, \& Mann, 1995). Young male rhesus macaques that were raised by peers exhibited lower CSF 5-HIAA than those raised by their mothers (Higley, Suomi, \& Linnoila, 1996a). In the same study, young male macaques with low CSF 5-HIAA and those less competent in social behaviors consumed more alcohol than monkeys with high CSF 5-HIAA or those that were more socially competent. In a companion article, Higley, Suomi, and Linnoila (1996b) reported that low CSF 5-HIAA was associated with low social dominance (measured by tests in which animals competed for food). To assess the impact of CSF 5-HIAA differences in survival to adulthood, Higley, Mehlman, et al. (1996) monitored 49 free-ranging macaques over 4 years and found low CSF 5-HIAA to be a robust predictor of aggression and premature death.

Reviewing clinical research related to alcohol, LeMarquand et al. (1994a) concluded that lowered central serotonin neurotransmission appears to be associated with alcoholism among some but not all samples. The AAL subtype may be specifically associated with lower serotonin function. Most studies to date have not separated subtypes for biological studies. Even so, evidence is accumulating that AAL might be associated with preexisting low serotonin activity (first proposed by Ballenger, Goodwin, Major, \& Brown, 1979).

CSF 5-HIAA measures on patients with early onset or antisocial characteristics (i.e., AAL) or both have consistently been lower than for nonalcoholic community samples or NAAL patients (Ballenger et al., 1979; Fils-Aime et al., 1996; Roy \& Linnoila, 1989; Roy, Virkkunen, \& Linnoila, 1987), which is interpreted as reduced central serotonin turnover (Roy et al., 1987). Furthermore, this finding has been repeated in comparisons of sons of antisocial alcoholics with sons of nonantisocial alcoholics (Virkkunen, Eggert, Rawlings, \& Linnoila, 1996; Virkkunen \& Linnoila, 1993). Associations have been reported between low CSF 5-HIAA and lifetime aggression scores (Limson et al., 1991). Virkkunen and Linnoila concluded that testosterone affects outward-directed aggression, whereas low 5-HIAA is related to impulsiveness.

Serotonergic responsivity in the limbic system and hypothalamus is tested by single-dose challenges with direct or indirect-acting serotonin agonists (D. L. Murphy, Mueller, Garrick, \& Aulakh, 1986; D. L. Murphy, 1990). Lee and Meltzer (1991) found alcoholic men to have 
a decreased pituitary response to the 5-HT precursor, L-5-hydroxytryptophan (L-5-HTP), and to the 5-HT2C receptor agonist, MK-212, compared with normal controls. The serotonin releasing agent, fenfluramine, also serves as a challenge that generally produces a large prolactin increase; blunted response to this agent in a sample of patients with personality disorder but not alcoholism nor antisocial traits has been associated with family history of impulsive aggression (Coccaro, Kavoussi, Sheline, Lish, \& Csernansky, 1996).

Several experimental studies have involved administration of the $5-\mathrm{HT}_{2} \mathrm{C}$ receptor agonist $m$-chlorophenylpiperazine ( $m$-CPP) to abstinent alcoholics, resulting in subjective alcohollike effects, alcohol craving, and blunted neuroendocrine responses (Benkelfat et al., 1991; Krystal, Webb, Cooney, Kranzler, \& Charney, 1994). Cortisol responses to $m$-CPP in detoxified alcoholics were also blunted, which may reflect reduced $5-\mathrm{HT}_{2} \mathrm{C}$ receptor function (Krystal et al., 1996; George et al., 1997). Prolactin responses to $m$-CPP were similarly blunted in subjects with antisocial personality disorder and substance abuse (Moss, Yao, \& Panzak, 1990). In another study with abstinent alcoholics, prolactin response to $m$-CPP was inversely correlated with trait measures of irritability and depression, although there was no significant blunting on average for the heterogeneous sample tested. BuydensBranchey, Branchey, Ferguson, Hudson, and McKernin (1997) reported that $m$-CPP decreased craving for alcohol and intensified a "high" feeling in alcoholics but not in healthy control subjects. New studies with subtypes of alcoholics revealed distinct subjective responses to $m$-CPP (George et al., 1997); AAL-type subjects (early onset and antisocial traits) reported euphoria, whereas NAAL-type subjects reported anxiety. The authors interpret the differential response as $m$-CPP's facilitation of the expression of preexisting symptoms rather than the induction of emotion by $m$-CPP (George et al., 1997). There is justification for further investigations of the relationships among preexisting hostility, alcoholism typology, and subjective response to agents affecting $5-\mathrm{HT}_{2} \mathrm{C}$ receptor function. A more specific agent than $m$-CPP might yield clearer experimental results because $m$-CPP is also an antagonist of 5- $\mathrm{HT}_{3}$ and $5-\mathrm{HT}_{2 \mathrm{~A}}$ receptors, in addition to having a high affinity for 5- $\mathrm{HT}_{2} \mathrm{C}$ receptors (Roth, 1994).

In two other experimental studies, researchers examined subjective responses to alcohol that had been combined with agents that affect serotonin receptors. No effects on subjective alcohol intoxication were shown for a 5- $\mathrm{HT}_{2 \mathrm{~A}}$ antagonist, ritanserin (Estevez, Parrillo, Giusti, \& Monti, 1995). The sample size was small $(N=12)$, however; the only detectable effect of ritanserin was on fatigue (i.e., levels of tiredness and alertness). Ondonsetron, a $5-\mathrm{HT}_{3}$ antagonist, affected subjective intoxication in a similar experiment $(N=12)$ that used a slightly higher alcohol dose (Swift, Davidson, Whelihan, \& Kuznetsov, 1996; 0.65g/kg vs. $0.5 \mathrm{~g} / \mathrm{kg}$ in Estevez et al., 1995). Ondonsetron increased both the sedative and impairing effects and the stimulant effects of alcohol; subjects reported feeling more intoxicated during the ondonsetron than the placebo session (Swift et al., 1996). Earlier studies with lower doses of alcohol and ondonsetron had shown no effect on subjective response to alcohol (Doty, Zacny, \& deWit, 1994) nor a reduction in positive moods measured by visual analog scales (B. A. Johnson, Campling, Griffiths, \& Cowen, 1993). Further studies with a standard experimental design are warranted to understand these conflicting results.

AAL patients appear to have more active reuptake of serotonin from the synapse. Serotonin uptake was higher in blood platelets from alcoholics and former alcoholics than 
healthy controls (Boismare et al., 1987). In fact, serotonin uptake in platelets has been shown to be higher in a group of individuals with alcoholic fathers than in a control group (Ernouf et al., 1993; Meltzer \& Arora, 1988). Results are not consistent across patient groups, however. Same et al. (1995) found a positive correlation between imipramine binding to platelets (a measure of 5-HT transporter action) and hostility (in samples of schizophrenics and criminal offenders but not normal controls), whereas Coccaro et al. (1996) found a negative association between the number of platelet 5-HT transporter sites and a life history of aggressive behavior in patients with personality disorder but not normal controls.

The AAL subtype may be associated with reduced monoamine oxidase (MAO) activity. Results that seemed inconsistent at first appear to be more consistent when groups are subdivided by typology. Initial studies were conflicting about whether MAO activity is reduced in alcoholics (positive findings; Lykouras, Markianos, \& Moussas, 1989; Sullivan, Stanfield, Schanberg, \& Cavenar, 1978; Wieberg, Gottfries, \& Oreland, 1977; negative findings: Tabakoff et al., 1988; von Knorring, Bohman, von Knorring, \& Oreland, 1985). When alcoholics were subdivided according to onset or other AAL features, reduced MAO activity was found more consistently (Sherif, Hallman, \& Oreland, 1992; von Knorring et al., 1985). Platelet MAO activity was about one standard deviation lower in Type II alcoholic patients (early onset with violence, arrests, or other substance abuse but not necessarily antisocial personality disorder) compared with Type I patients (Hallman, von Knorring, \& Oreland, 1996).

Thus, results from current physiological literature support a deficit in 5-HT function among antisocial alcoholics, but there is not sufficient converging evidence directed to a specific dysfunctional component. A complete scan of all components will be required to uncover the primary underlying deficit; one primary deficit could cause apparent differences in many components resulting from adaptation or compensation by other parts of the system. Integrating the relevant findings is made more complicated by paradoxical effects, such as associations of lower MAO, which degrades serotonin, with the same responses that are associated with lower serotonin. Kranzler and Anton (1994) interpreted $m$-CPP challenge findings as indicating that alcoholics may have low 5-HT synthesis, which would lead to up-regulation of receptors, which would then be abnormally sensitive to agonists. Similarly, 5-HT1A agonists produce complex results, probably because this receptor type is both an autoreceptor (i.e., presynaptic) and a postsynaptic receptor (Benkelfat, 1993). As another example, lowered 5-HIAA could result from decreased 5-HT synthesis and thus would be associated with less transmission, or lower 5-HIAA could result from decreased degradation, which would be associated with more transmission.

The likelihood that there are genetic lesions in all these components is minuscule. Rather, it is likely that there is a primary abnormality, and other dysregulation results from functional alterations by serotonin neurons to compensate for one primary deficit. By examining multiple markers in the serotonin pathway, researchers are more likely to uncover a deficit that is primary. Current studies will necessarily be limited by the feasibility of studying particular markers; a review of available polymorphisms follows. 


\section{Serotonin-Related Genetic Polymorphisms and AAL}

Genetic markers have become available for characterizing important components of serotonin synthesis and metabolism. Table 2 lists known markers and evidence for functional significance. Genetic studies are cited; functional evidence from Table 1 is noted where no genetic studies are available. Markers are located on autosomal and $\mathrm{X}$ chromosomes (autosomal: TPH, HTR1A, HTR1B, HTR2A, HTR3, SLC6A4, HTTLPR; and X: HTR2C, MAOA, $\mathrm{MAOB})$. Animal research will be noted, and then molecular genetic studies with humans will be described.

\begin{tabular}{|c|c|c|c|c|c|}
\hline Component & Chrom. & Gene $^{a}$ & Genetic association $^{\mathrm{b}}$ & Sample & Reference \\
\hline \multicolumn{6}{|l|}{ Synthesis } \\
\hline $\begin{array}{l}\text { Tryptophan } \\
\text { hydroxylase }\end{array}$ & 11p15 & $+\mathrm{TPH}$ & Assoc. w/ suicidality & AAL patients & $\begin{array}{l}\text { Nielsen et al., } \\
1994\end{array}$ \\
\hline \multicolumn{6}{|l|}{ Activity } \\
\hline 5-HT1A receptor & 5q11-q13 & + HTR1A & See Table 1 & & \\
\hline \multirow{3}{*}{$\begin{array}{l}\text { 5- } \mathrm{HT}_{1 \mathrm{~B}} \text { receptor } \\
\text { (in humans } \\
\left.\text { 5- } \mathrm{HT}_{1 \mathrm{D} \beta}\right)\end{array}$} & $6 \mathrm{q} 13$ & + HTR1B & $\begin{array}{l}\text { Deletion in mouse } \\
\rightarrow \text { aggression }\end{array}$ & Knock-out mice & $\begin{array}{l}\text { Saudou et al., } \\
1994\end{array}$ \\
\hline & & & $\begin{array}{l}\text { Deletion in mouse } \\
\rightarrow \text { more drinking }\end{array}$ & Knock-out mice & $\begin{array}{l}\text { Crabbe et al., } \\
1996\end{array}$ \\
\hline & & & $\begin{array}{l}\text { Assoc. w/ antisocial } \\
\text { alcoholism } \\
\text { diagnosis }\end{array}$ & $\begin{array}{l}\text { Navaho and } \\
\text { Finnish } \\
\text { families }\end{array}$ & $\begin{array}{c}\text { Lappalainen } \\
\text { et al., } 1998\end{array}$ \\
\hline $\begin{array}{l}\text { 5- } \mathrm{HT}_{2 \mathrm{~A}} \text { receptor } \\
\text { (previously } \\
\left.5-\mathrm{HT}_{2}\right)\end{array}$ & $13 q 14-q 21$ & + HTR2A & See Table 1 & & \\
\hline \multirow{2}{*}{ 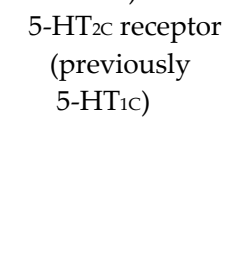 } & $X q 24$ & + HTR2C & $\begin{array}{l}\text { Prelim. marker assoc. } \\
\text { w/ alcoholism }\end{array}$ & $\begin{array}{l}\text { Finnish } \\
\text { families }\end{array}$ & Goldman, 1995 \\
\hline & & & $\begin{array}{l}\text { Prelim. marker assoc. } \\
\text { w/ TPQ persistence } \\
\text { and reward } \\
\text { dependence }\end{array}$ & $\begin{array}{l}\text { Mixed } \\
\text { volunteers }\end{array}$ & $\begin{array}{l}\text { Ebstein et al., } \\
1997\end{array}$ \\
\hline 5-HT3 receptor & $11 \mathrm{q} 23$ & - HTR3 & See Table 1 & & \\
\hline \multicolumn{6}{|l|}{ Reuptake } \\
\hline $\begin{array}{l}\text { Serotonin } \\
\text { transporter }\end{array}$ & $17 q 11-q 12$ & + SLC6A4 & See Table 1 & & \\
\hline \multirow[t]{2}{*}{$\begin{array}{c}\text { Transporter } \\
\text { promoter }\end{array}$} & $17 \mathrm{q} 12$ & + HTTLPR & $\begin{array}{l}\text { Assoc. w/ TPQ } \\
\text { harm avoidance }\end{array}$ & $\begin{array}{l}\text { Mixed } \\
\text { volunteers }\end{array}$ & Lesch et al, 1996 \\
\hline & & & $\begin{array}{l}\text { Assoc. w/ severe } \\
\text { alcohol dependence }\end{array}$ & $\begin{array}{l}\text { Alc.-dep./ } \\
\text { severe } \\
\text { withdrawal }\end{array}$ & $\begin{array}{l}\text { Sander et al., } \\
1997\end{array}$ \\
\hline
\end{tabular}




\begin{tabular}{|c|c|c|c|c|c|}
\hline Component & Chrom. & Gene $^{a}$ & Genetic association $^{b}$ & Sample & Reference \\
\hline \multicolumn{6}{|l|}{ Metabolism } \\
\hline \multirow[t]{3}{*}{$\begin{array}{c}\text { Monoamine } \\
\text { oxidase A }\end{array}$} & Xp11 & + MAOA & $\begin{array}{l}\text { Deletion in mouse } \\
\rightarrow \text { aggression }\end{array}$ & $\begin{array}{l}\mathrm{C} 3 \mathrm{H} \text { transgenic } \\
\text { mice }\end{array}$ & $\begin{array}{l}\text { Cases et al., } \\
1995\end{array}$ \\
\hline & & & $\begin{array}{l}\text { Deletion assoc. w/ } \\
\text { Brunner syndrome }\end{array}$ & Dutch families & $\begin{array}{l}\text { Brunner et al., } \\
1993\end{array}$ \\
\hline & & & $\begin{array}{l}\text { Prelim. marker assoc. } \\
\text { w/ early-onset } \\
\text { alcoholism }\end{array}$ & $\begin{array}{l}\text { Adol. sub. ab. } \\
\text { patients }\end{array}$ & $\begin{array}{l}\text { Vayukov et al., } \\
1995\end{array}$ \\
\hline $\begin{array}{c}\text { Monoamine } \\
\text { oxidase B }\end{array}$ & Xp11 & $+\mathrm{MAOB}$ & See Table 1 & & \\
\hline
\end{tabular}

Note: Chrom. $=$ chromosome, assoc. $=$ associated, prelim. $=$ preliminary, alc. -dep.$=$ alcohol-dependent, $\mathrm{TPQ}=$ Tridimensional Personality Questionnaire, adol. = adolescent, sub. ab. = substance abuse aGenes with reported polymorphisms are shown with a + .

bDetails are given for molecular genetic studies; "see Table 1" is noted where functional evidence refers to the physiological work previously listed in Table 1.

Genetic markers for several receptors have been studied. An exciting recent finding implicates the 5- $\mathrm{HT}_{1 в}$ receptor. Null mutant mice lacking the gene for this receptor drank twice as much alcohol as wild mice and also showed less sensitivity to alcohol's ataxic effects (Crabbe et al., 1996). The 5-НТів receptor gene has been implicated in studies mapping quantitative trait loci that are associated with differences in drinking behavior or response to alcohol (Phillips, Crabbe, Metten, \& Belknap, 1994). Mice with an experimental deletion of the gene for the 5-HТ1в receptor show high levels of aggression (Saudou et al., 1994). The coupling of aggression with alcohol consumption is again seen with animal genetic research. One marker related to reuptake has been studied in a "knock-out" mouse strain with a deletion of MAOA; this experimental animal is abnormally aggressive (Cases et al., 1995).

Molecular genetic studies with humans have involved markers related to synthesis, activity, and reuptake and have included clinical samples with alcoholism, violence disorders, or both, and community samples with varying levels of impulsive personality traits. At the NIAAA LN, an intensive initiative is underway to examine linkage of alcoholism to serotonin markers (Goldman, 1995). The gene for tryptophan hydroxylase (TPH), which codes for the rate-limiting enzyme in the biosynthesis of serotonin, has been isolated (Nielsen, Dean, \& Goldman, 1992; Stoll \& Goldman, 1991). One of the two TPH alleles was associated with CSF 5-HIAA concentration and a history of suicide attempts in a subgroup of impulsive, alcoholic, violent offenders. Although no TPH allele association was found when categories of impulsive and nonimpulsive offenders were compared, the use of standardized measures of impulsivity may better detect an association (Nielsen et al., 1994). Abbar et al. (1995), however, did not find an association between TPH and a history of suicide attempts; they did not attempt to measure impulsivity. The TPH polymorphism is probably not functionally significant because it is located in an intron (Nielsen et al., 1994). Rather, it may be in disequilibrium to a variant that does affect activity of TPH (Nielsen et al., 1994). Tryptophan oxygenase, a marker for which is located on 4q31, has been suggested as a candidate gene for alcoholism because it converts L-tryptophan to kynurenine, 
reducing tryptophan availability (Comings, Muhleman, Dietz, \& Donlon, 1991). This enzyme has not been studied in alcoholic patients, however, and will not be discussed further.

Several genes related to serotonin receptors have been tested in association studies. Polymorphisms have been published for the gene for the 5-HT1A receptor (HTR1A; Warren, Peacock, \& Fink, 1992), but no studies with alcoholism have been performed. The gene for the human receptor 5- $\mathrm{HT}_{1 \mathrm{~B}} / 5-\mathrm{HT}_{1 \mathrm{D} \beta}$ (identical according to Hamblin, McGuffin, Metcalf, Dorsa, \& Merchant, 1992) is listed as HTR1B. Researchers at the NIAAA LN reported an association with antisocial alcoholism of a silent polymorphism in HTR1B (Lappalainen et al., 1998; Lappalainen, Dean, et al., 1995). The sample comprised southwestern Indians and Finnish patients with antisocial alcoholism. The 5-HT2A receptor gene (HTR2A; Sparkes et al., 1991) has been linked closely to esterase D (Hsieh et al., 1990), but no molecular genetic studies with alcoholism have been reported. The gene for the 5-HT3 receptor has recently been localized (Weiss, Mertz, Schrock, Koenen, \& Rappold, 1995), but no polymorphism has been described. Once a polymorphism has been reported, it will be a promising marker to test, especially among NAAL patients, because anxiety and depression are common in this subgroup. In a study of NAAL-type Finnish patients, a preliminary association with alcoholism was reported, with the 5-HT2C Cys23-Ser23 variant (HTR2C; Goldman et al., 1995; Lappalainen, Zhang, et al., 1995). It is interesting to note that this marker showed some evidence of association with the personality measures of persistence and reward dependence when polymorphisms were tested jointly for HTR2C and two dopamine receptor markers (Ebstein et al., 1997). No association with harm avoidance was found, but sample sizes were small for the less frequent 2ser allele.

Related to reuptake, the gene for the serotonin transporter, SLC6A4, has been cloned (Blakely et al., 1991; Hoffman, Mezey, \& Brownstein, 1991). In addition, a marker for the regulatory region that modulates transcription has been localized nearby (HTTLPR; Lesch et al., 1996). Association studies with this marker among individuals and sibships show a small but significant contribution to variance in anxiety-related traits, as measured by personality scales (Lesch et al., 1996). One of these was a subscale of the Tridimensional Personality Questionnaire, Harm Avoidance, which is related to Cloninger's concept of the impulsive-aggressive personality cluster as having low harm avoidance (Cloninger, 1987b). Recently, the "short" variant of the promoter (HTTLPR) showed association with a narrow clinical phenotype, a subgroup of alcoholic patients who experienced severe withdrawal symptoms compared with a control group (Sander et al., 1997). MAOA and MAOB are tightly linked on the X chromosome (Harris, Kurth, Barnes, Bowcock, \& Kurth, 1993; Hotamisligil \& Breakefield, 1991). Although it is responsible for platelet MAO activity, a complete deficiency of MAOB may not interfere with 5-HT metabolism, however (Lenders et al., 1997). A null mutation in the MAOA gene has been linked to impulsive violence in an extended family with male members prone to aggressive, violent outbursts (Brunner, Nelen, Breakefield, Ropers, \& van Oost, 1993). Alcoholism did not co-occur with these outbursts, however. One MAOA polymorphism has been examined in patients with early onset substance abuse (Vanyukov, Moss, Yu, Tarter, \& Deka, 1995). The long repeat allele of a dinucleotide repeat-length polymorphism was associated in young men but not young women. Conduct disorder symptoms were not specified in these young people (mean age was 15 years). 
Thus, several recent findings are highly suggestive of associations between alcoholism, impulsivity, aggression, and components of serotonin neurotransmission. Particularly promising are the receptor markers HTR1B and HTR2C, along with markers for synthesis and reuptake components. None of these preliminary associations have been confirmed using families or methods that are conclusive, such as the haplotype relative risk method, which prevents confounding by ethnic differences between control and affected groups (see below). All genes listed in Table 2 should be studied. However, no polymorphism has been reported so far for HTR3 and HTR4. If certain components of the serotonin system can be shown to be implicated in conferring vulnerability to $\mathrm{AAL}$, then those components are logical target sites for pharmacotherapy.

\section{Serotonergic Pharmacotherapy in AAL}

Recent advances in the pharmacotherapy of alcoholism were reviewed in detail by Litten, Allen, and Fertig (1996) and Schuckit (1996). Pettinati (1996) reviewed research specifically related to serotonergic agents. Clinical trials have been conducted or are in progress with several classes of drugs. For almost 50 years, the only medication approved for alcoholism treatment by the U.S. Food and Drug Administration was disulfiram (Antabuse), an aversive therapy that, when combined with alcohol, produces headache, nausea, respiratory problems, and palpitations. It is used effectively as an adjunct treatment to psychosocial therapy in a monitored setting (Fuller et al., 1986). The only other medication to be approved for use in alcoholism treatment is naltrexone, an opioid antagonist. Recent trials have shown naltrexone to reduce alcohol craving and consumption among male patients (O'Malley et al., 1992; Volpicelli, Alterman, Hayashida, \& O’Brien, 1992). Acamprosate (calcium acetylhomotaurinate) has shown significant effects on relapse rates and consumption frequency in clinical trials in Europe (Whitworth et al., 1996); the mechanism of action is unclear. Recent neuroscience research has implicated dopamine, opioids, and serotonin, all acting in areas of the limbic system, as underlying alcohol preference (Hunt, 1993). These neurotransmitter systems may be arenas for future pharmacology development. It is unknown whether the alcoholism subtypes discussed above would show differential response to naltrexone; laboratory studies with social drinkers have provided some evidence that alcoholism family history may affect response to naltrexone with alcohol (King, Volpicelli, Frazer, \& O'Brien, 1997). Gerra et al. (1992) conducted a crossover trial of fluoxetine and acamprosate and analyzed the results by patients' family history. Subjects with a family history of alcoholism responded better to fluoxetine than acamprosate and vice versa. Subtyping of alcoholics becomes more interesting as more details are known about interactions of these neurotransmitter systems.

Potential alcoholism treatment medications have been tested specifically to ameliorate 5-HT dysregulation (see Pettinati, 1996, for a recent review). Table 3 summarizes the medications that affect serotonin system components discussed above. Some components do not have commercially available agents. Other components, which are affected by familiar agents (e.g., MAO inhibitors), have not been tested in clinical trials with alcoholic patients. Nor should they necessarily be tested, particularly agents with broad effects, such as MAO inhibitors and SSRIs. Negative clinical trials have been reported with administration of the 
precursor to serotonin, tryptophan (George et al., 1992). Table 3 summarizes which agents affect which components of the 5-HT system. It is not at all clear that each agent listed would have a beneficial effect.

\begin{tabular}{|c|c|c|c|c|c|}
\hline Component & Gene $^{a}$ & Pharmacotherapy & Clinical efficacy & Sample & Reference \\
\hline \multicolumn{6}{|l|}{ Synthesis } \\
\hline $\begin{array}{l}\text { Tryptophan } \\
\text { hydroxylase }\end{array}$ & $+\mathrm{TPH}$ & Tryptophan & Negative & $\begin{array}{l}\text { Alc.-dep. } \\
\text { patients }\end{array}$ & $\begin{array}{l}\text { George et al., } \\
1992\end{array}$ \\
\hline \multicolumn{6}{|l|}{ Activity } \\
\hline \multirow[t]{3}{*}{ 5-HT1A receptor } & + HTR1A & $\begin{array}{l}\text { Buspirone } \\
\quad \text { (partial agoninst) }\end{array}$ & Positive & $\begin{array}{l}\text { Anx./alc. } \\
\text { patients }\end{array}$ & $\begin{array}{l}\text { Tollefson et al., } \\
1992\end{array}$ \\
\hline & & & & & $\begin{array}{l}\text { Kranzler et al., } \\
1994\end{array}$ \\
\hline & & & Negative & $\begin{array}{l}\text { Anx./alc. } \\
\text { patients }\end{array}$ & $\begin{array}{l}\text { Malcolm et al., } \\
1992\end{array}$ \\
\hline $\begin{array}{l}\text { 5-HT1в receptor } \\
\text { (in humans } \\
5-\mathrm{HT}_{1 \mathrm{D} \beta} \text { ) }\end{array}$ & + HTR1B & None & None & & \\
\hline \multirow{4}{*}{$\begin{array}{c}\text { 5- } \mathrm{HT}_{2 \mathrm{~A}} \text { receptor } \\
\text { (previously } \\
\left.5-\mathrm{HT}_{2}\right)\end{array}$} & + HTR2A & $\begin{array}{l}\text { Ritanserin } \\
\quad \text { (antagonist) }\end{array}$ & Mildly positive & $\begin{array}{l}\text { Alc.-dep. } \\
\text { patients }\end{array}$ & $\begin{array}{r}\text { Monti and Al- } \\
\text { terwain, } 1991\end{array}$ \\
\hline & & & Negative & $\begin{array}{l}\text { Heavy } \\
\text { drinkers }\end{array}$ & $\begin{array}{l}\text { Naranjo, Pou- } \\
\text { los, et al., } 1995\end{array}$ \\
\hline & & & Negative & & \\
\hline & & & Negative & $\begin{array}{l}\text { Alc.-dep. } \\
\text { patients }\end{array}$ & $\begin{array}{l}\text { B. A. Johnson, } \\
\text { Jasinski, et } \\
\text { al., } 1996\end{array}$ \\
\hline $\begin{array}{c}\text { 5-HT2 receptor } \\
\text { (previously } \\
\text { 5-HT1c) }\end{array}$ & + HTR2C & $\begin{array}{l}\text { m-CPP; MK-212 } \\
\text { (agonists) }\end{array}$ & None & & \\
\hline 5-HT3 receptor & - HTR3 & $\begin{array}{l}\text { Ondonsetron } \\
\text { (antagonist) }\end{array}$ & $\begin{array}{l}\text { Some reduction } \\
\text { of intake }\end{array}$ & $\begin{array}{l}\text { Alc.-dep. } \\
\text { patients }\end{array}$ & $\begin{array}{l}\text { Sellers et al., } \\
1994\end{array}$ \\
\hline \multicolumn{6}{|l|}{ Reuptake } \\
\hline $\begin{array}{l}\text { Serotonin } \\
\text { transporter }\end{array}$ & + SLC6A4 & SSRIs ${ }^{b}$ & Positive & $\begin{array}{l}\text { Alc.-dep. } \\
\text { patients }\end{array}$ & $\begin{array}{l}\text { Tiihonen et al., } \\
1996\end{array}$ \\
\hline \multirow[t]{2}{*}{$\begin{array}{c}\text { Transporter } \\
\text { promoter }\end{array}$} & + HTTLPR & & Negative & $\begin{array}{l}\text { Alc.-dep. } \\
\text { patients }\end{array}$ & $\begin{array}{l}\text { Kabel and } \\
\text { Petty, } 1996\end{array}$ \\
\hline & & & $\begin{array}{l}\text { See text for pre- } \\
1995 \text { studies }\end{array}$ & & \\
\hline \multicolumn{6}{|l|}{ Metabolism } \\
\hline $\begin{array}{c}\text { Monoamine } \\
\text { oxidase A }\end{array}$ & + MAOA & None & None & & \\
\hline $\begin{array}{c}\text { Monoamine } \\
\text { oxidase B }\end{array}$ & $+\mathrm{MAOB}$ & MAO inhibitors & None & & \\
\hline
\end{tabular}

Note: SSRIs = selective serotonin reuptake inhibitors, alc.-dep. = alcohol-dependent, anx./alc. = anxiety/alcoholism

${ }^{a}$ Genes with reported polymorphisms are shown with a + .

bFor example, fluoxetine, zimelidine, citalopram, viqualine, sertraline, paroxetine. 
The most extensive research has used the class of antidepressant agents that selectively inhibit SSRIs, which includes fluoxetine, zimelidine, citalopram, viqualine, sertraline, and paroxetine. Even though multiple studies have been conducted, a clear pattern of results has not emerged (Litten et al., 1996; Pettinati, 1996). Results are not consistent when patient groups are subdivided by alcoholism severity, by type of medication, nor by definition of relapse. Early studies showed positive results for samples with alcohol problems (variously defined as alcohol abusers or heavy drinkers; Gatto, Murphy, McBride, Lumeng, \& Li, 1990; Gorelick, 1989; Naranjo \& Sellers, 1989; Naranjo et al., 1987) but less promising results for patients with alcohol dependence (mixed results from multiple trials are reviewed in Pettinati, 1996). In two recent, large studies of fluoxetine in combination with relapse prevention therapy for alcoholdependent patients, Kranzler et al. (1995) and Naranjo, Bremner, and Lanctot (1995) were unable to demonstrate any significant beneficial effect of the active drug on alcohol consumption. The authors offered the sample constitution as a possible explanation for their negative finding; most patients fit an NAAL classification, and they are less likely to show serotonergic dysfunction than AAL patients. Researchers also analyzed outcome results in a trial of fluoxetine; they examined an interaction between subtype and medication (Kranzler, Burleson, Brown, \& Babor, 1996). AAL patients fared worse with active medication than with placebo, whereas no medication effect occurred with NAAL patients. Kranzler et al. (1996) speculated that fluoxetine may have agonist effects at $5-\mathrm{HT}_{2} \mathrm{C}$ receptors that produce subjective responses resembling those of alcohol, as has been suggested for $m$-CPP (see above). Further research on the serotonergic dysfunction associated with AAL should be conducted, but further pharmacologic trials with broadly acting agents such as SSRIs are not warranted in AAL populations; agents targeting specific receptors might be more promising.

Some specific serotonin receptor agents have been used in clinical trials. Ritanserin, primarily an antagonist of 5- $\mathrm{HT}_{2 \mathrm{~A}}$ receptors, showed potential usefulness in an open trial (Monti \& Alterwain, 1991) but did not succeed in a double-blind, multisite trial (Johnson, Jasinski, et al., 1996). Both of these studies were with patients having moderate alcohol dependence. In addition, Naranjo, Poulos, et al. (1995) found little evidence of ritanseran's efficacy for reducing consumption in heavy social drinkers during a 2-week trial. Ondonsetron, a 5- $\mathrm{HT}_{3}$ antagonist, showed some efficacy in reducing drinking in a sample of lighter drinkers (Sellers et al., 1994). These patients were probably not AAL, but 5-HT3 is worthy of future investigation; $5-\mathrm{HT}_{3}$ antagonists may decrease the reinforcing properties of ethanol by interfering with alcohol's rewarding activation of the mesolimbic dopaminergic system (cf. LeMarquand et al., 1994b; Sellers et al., 1994). Trials with buspirone, a partial agonist for 5-HT1A receptors, have been conducted with patients with comorbid alcoholism and anxiety disorder. Two studies showed significant reductions in both disorders (Tollefson, Montague-Clouse, \& Tollefson, 1992; Kranzler et al., 1994), but a third failed to find a benefit (Malcolm etal., 1992).

In summary, clinical trials with serotonergic medications have had very mixed results. Schuckit (1996) concluded that no medication has a level of efficacy convincing enough to recommend it for routine use, but that naltrexone and acamprosate have shown promise. He suggested that dopamine boosters might have interesting possibilities and that some patients with comorbid psychiatric disorders may benefit from buspirone or SSRIs. Trials 
in which patients are grouped by alcoholism subtype are lacking, however. Serotonin dysfunction is only expected to be present for the antisocial subtype of alcoholism. As described above, abnormalities of specific receptors are also involved in this disorder, probably including $5-\mathrm{HT}_{1 в}\left(5-\mathrm{HT}_{1 \mathrm{D} \beta}\right)$ and $5-\mathrm{HT}_{2 \mathrm{C}}$. On the basis of evidence reviewed above from animal work, human experiments, and genetic association studies, medications affecting these receptors need to be studied. Further clinical trials are not justified, however, until the roles of specific receptors are better understood.

\section{Discussion}

There is ample evidence that the serotonin system is involved in variation among individuals who have AAL, but a primary defective component is not clear. Differences in 5-HT level could be due to a polymorphism in TPH, the 5-HT transporter, or MAOA or MAOB. It is likely that there is a primary abnormality, and other dysregulation results from functional alterations by serotonin neurons to compensate for one primary deficit. Differences in serotonin function could also be due to polymorphisms that affect binding in any of the receptor types. Specific syndromic manifestations (e.g., depression, anxiety, or alcoholism) may be due to particular receptors involved. LeMarquand et al. (1994a) speculated that various serotonin receptors may be involved in different components of alcohol craving and intake, specifically that $2 \mathrm{~A}$ and 3 may affect reward but not consumption behavior, $2 \mathrm{C}$ may produce an intoxicated feeling, and $1 \mathrm{~A}$ may affect both craving and consumption. Thus, even with normal serotonin levels, deficits could exist in postsynaptic receptors. In such a case, routine function may usually be adequate, but problems are revealed when the system is subjected to stress. Alternately, the threshold for deficient functioning under stress may be low, whereas less sensitive systems can better resist stress.

Physiological studies suggest that AAL is related to lower central serotonin levels and lower serotonin turnover (lower CSF 5-HIAA). However, MAO activity appears lower, which could leave more 5-HT in the synapse, whereas transporter activity is higher, which would lower synaptic levels. The other consistent finding is reduced 5-HT2c receptor functioning ( $m$-CPP challenge studies). Several recent genetic studies suggest associations between alcoholism, aggression, impulsivity, and the genes for 5- $\mathrm{HT}_{2 \mathrm{C}}$ and $5-\mathrm{HT}_{1 \mathrm{~B}}$ receptors, along with markers related to synthesis (i.e., TPH) and degradation (i.e., HTTLPR, MAOA). Schuckit (1996) noted five proposed mechanisms for a serotonin role in alcoholism: (a) 5-HT activity is low in people vulnerable to alcoholism, and alcohol boosts it; (b) 5-HT contributes to the effect of alcohol on dopamine activity in reward pathways; (c) low 5-HT might increase impulsivity and impair self-regulation of consumption; (d) anxiety might be increased by low 5-HT levels, precipitating self-medication with alcohol; and (e) 5-HT might be involved in general appetitive behaviors, rather than having effects specific to alcohol (p. 671). Kranzler and Anton (1994) proposed that serotonergic and opioidergic agents exert their consumption-reducing effect through interactions with reward pathways subserved by dopamine. The evidence reviewed above does not definitively falsify any of these proposals. There is evidence that serotonin may affect impulsivity, which would have general effects on appetitive behavior. Several of the serotonin receptors affect dopamine reward pathways; thus, effects of these agents on alcohol consumption might be 
mediated by dopamine. For alcohol dependence to develop, deficits in several systems might be required, such as a different subjective response to alcohol coupled with a different capacity for behavioral regulation. If so, areas for future study include combinations of medications and interactions among the serotonin, opiate, and dopamine systems, as advocated by Le, Tomkins, and Sellers (1996) and Anton (1996).

The most relevant question to be asked in studies of the genetic basis of alcoholism is no longer whether there are genetic factors that influence alcoholism, but rather which genes are involved in the complex biopsychosocial matrix that confers vulnerability to alcoholism. Once genes that influence vulnerability to alcoholism are identified, the question then becomes how those genes interact with each other and with complex and variable environments. Then it may be possible to develop medications that can be part of the arsenal of treatments for alcoholism. One strategy that will be important for identifying such vulnerability factors is the family-based association study in which specific allele frequencies of affected cases are compared with allele frequencies of unaffected relatives for genes thought to be involved in the development of the trait of interest. In this article, we have reviewed the evidence for serotonergic system involvement in the AAL subtype, and we recommend further family-based studies.

Family-based studies are superior in methods to population-based studies that compare affected cases with unaffected controls (i.e., case/control studies). As mentioned earlier, case/control associations between certain components of the dopaminergic system and alcoholism have been reported, although the findings have been inconsistent. In a metaanalysis that pooled data from eight studies, Pato et al. (1993) found a statistically significant association: A higher prevalence of the $\mathrm{Al}$ allele occurred in the alcoholism group (43.6\%) relative to the control group (26.8\%). It may be that the DRD2 receptor is a causal factor in alcoholism; however, Pato et al. also suggested the possibility that the observed association between DRD2 and alcoholism could be an artifact of the ethnic stratification of the affected and control groups. A potential pitfall of association studies is that positive associations can arise as a result of differential ethnic stratification of the affected and unaffected groups. This confounding factor is particularly likely for genes whose allele frequencies in normal populations vary considerably. If a certain allele is found more often in one ethnic group, and that group is over-represented in either the affected or unaffected group, a positive association between the trait of interest and that allele could be due to the allelic frequencies in those groups (Lander \& Schork, 1994). The Al allele of DRD2 has allele frequencies between 0.09 and 0.75, and is thus prone to stratification effects (Barr \& Kidd, 1993). Studies with ethnically homogeneous groups-for example, American Indians and Finnish Caucasians - have not found genetic associations between DRD2 and alcoholism (Goldman et al., 1993, 1992). A recent analysis of 105 families participating in the COGA study (see earlier) found no evidence of an association of A1 with alcoholism (Edenberg et al., 1998). This study had sufficient power and rigor to eliminate definitively a putative candidate gene.

The haplotype relative risk (HRR) method or the transmission disequilibrium test (TDT) should be used to reduce such spurious associations; both methods rely on comparisons among family members rather than between patient and control groups. In the HRR method (Falk \& Rubenstein, 1987; Rubenstein et al., 1981), the nontransmitted parental 
genotypes are used to create an artificial control genotype. The design requires ascertainment of a single affected proband and analysis of him or her and both parents, and it is considered to be a very effective way to control internally for genetic admixture (Lander \& Schork, 1994). The TDT method (McGinnis, Ewens, \& Spielman, 1995; Spielman, McGinnis, \& Ewens, 1993) involves affected probands and heterozygous parents. Both tests use a chi-square test statistic. Observed transmission probabilities for alleles are tested for deviations from an expected probability of .50 (TDT); the HRR compares the allele distribution from the affected proband with that of the constructed control on the basis of the parental genotypes.

The objective of our review was to present the evidence in favor of using family-based studies with candidate gene analysis to test the associations between components of a welldefined biological system and a well-defined phenotype. This approach could be productive in the examination of potential associations between components of the serotonergic system and AAL. We reviewed the substantial evidence that the serotonin system is associated with alcohol use and impulsivity as well as the evidence for a relatively homogeneous subtype of alcoholism. Association studies may help identify the specific components of the serotonergic system that confer vulnerability to AAL. Once identified, these components will be logical target sites for pharmacotherapy.

Acknowledgments - The authors thank Karley Little and Juan Lopez for valuable comments on drafts of this article. Preparation of this article was supported by Grants R21 AA10696, P50 AA0738, and T32 AA07477 from the National Institute on Alcohol Abuse and Alcoholism.

\section{References}

Abbar, M., Courtet, P., Amadeo, S., Caer, Y., Mallet, J., Baldy-Moulinier, M., Castelnau, D., \& Malafosse, A. (1995). Suicidal behaviors and the tryptophan hydroxylase gene. Archives of General Psychiatry, 52, 846-849.

Anton, R. F. (1996). Neurobehavioral basis for the pharmacotherapy of alcoholism: Current and future directions. Alcohol and Alcoholism, 37(Suppl. 1), 43-53.

Aurora, R. C., Tong, C., Jackman, H. L., Staff, D., \& Meltzer, H. Y. (1983). Serotonin uptake and imipramine binding in blood platelets and brain of fawn-hooded and Sprague-Dawley rats. Life Sciences, 33, 437-442.

Babor, T. F., Hoffman, M., Del Boca, F. K., Hesselbrock, V., Meyer, R. E., Dolinsky, Z. S., \& Rounsaville, B. (1992). Types of alcoholics, I: Evidence for an empirically derived typology based on indicators of vulnerability and severity. Archives of General Psychiatry, 49, 599-608.

Ballenger, J. C., Goodwin, F. K., Major, L. F., \& Brown, G. L. (1979). Alcohol and central serotonin metabolism in man. Archives of General Psychiatry, 36, 224-227.

Barr, C. L., \& Kidd, K. K. (1993). Population frequencies of the A1 allele at the dopamine $\mathrm{D}_{2}$ receptor locus. Biological Psychiatry, 34, 204-209.

Beardsley, P. M., Lopez, O. T., Gullikson, G., \& Flynn, D. (1994). Serotonin 5-HT3 antagonists fail to affect ethanol self-administration of rats. Alcohol, 11, 389-395.

Begleiter, H., Porjesz, B., Reich, T., Edenberg, H. J., Goate, A., Blangero, J., Almasy, L., Foroud, T., Van Eerdewegh, P., Polich, J., Rohrbaugh, J., Kuperman, S., Bauer, L. O., O'Connor, S. J., Chorlian, D. B., Li, T.-K., Conneally, P. M., Hesselbrock, V., Rice, J. P., Schuckit, M. A., Cloninger, R., 
Nurnberger, J., Jr., Crowe, R., \& Bloom, F. E. (1998). Quantitative trait loci analysis of human event-related brain potentials: P3 voltage. Electroencephalography and Clinical Neurophysiology, 108, 244-250.

Benkelfat, C. (1993). Serotonergic mechanisms in psychiatric disorders: New research tools, new ideas. International Clinical Psychopharmacology, 8, 53-56.

Benkelfat, C., Murphy, D. L., Hill, J. L., George, D. T., Nutt, D., \& Linnoila, M. (1991). Ethanol-like properties of the serotonergic partial agonist $m$-chlorophenylpiperazine in chronic alcoholic patients. Archives of General Psychiatry, 48, 383.

Blakely, R. D., Berson, H. E., Fremeau, R. T., Jr., Caron, M. G., Peek, M. M., Prince, H. K., \& Bradley, C. C. (1991). Cloning and expression of a functional serotonin transporter from rat brain. Nature, 354, 66-70.

Blum, K., Noble, E. P., Sheridan, P. J., Montgomery, A., Ritchie, T., Jagadeeswaran, P., Nogami, H., Briggs, A. H., \& Cohn, J. B. (1990). Allelic association of human dopamine D2 receptor gene in alcoholism. Journal of the American Medical Association, 263, 2055-2059.

Blumensohn, R., Ratzoni, G., Weizman, A., Israeli, M., Greuner, N., Apter, A., Tyano, S., \& Biegon, A. (1995). Reduction in serotonin 5HT2 receptor binding on platelets of delinquent adolescents. Psychopharmacology, 118, 354-356.

Boismare, R, \& Lhuintre, J. P., Daoust, M., Moore, N., Saligaut, C., \& Hillemand, B. (1987). Platelet affinity for serotonin is increased in alcoholics and former alcoholics: A biological marker for dependence? Alcohol and Alcoholism, 22, 155-159.

Brunner, H. G., Nelen, M., Breakefield, X. O., Ropers, H. H., \& van Oost, B. A. (1993, October 22). Abnormal behavior associated with a point mutation in the structural gene for monoamine oxidase A. Science, 262, 578-580.

Bushman, B. J., \& Cooper, H. M. (1990). Effects of alcohol on human aggression: An integrative research review. Psychological Bulletin, 107, 341-354.

Buydens-Branchey, L., Branchey, P., Ferguson, P., Hudson, S., \& McKernin, C. (1997) Hormonal, psychological, and alcohol craving changes after $m$-chlorophenylpiperazine administration in alcoholics. Alcoholism: Clinical and Experimental Research, 21, 220-226.

Cases, O., Seif, L, Grimsby, J., Caspar, P., Chen, K., Pournin, S., Muller, U., Aguet, M., Babinet, C., \& Shih, J. C. (1995, June 23). Aggressive behavior and altered amounts of brain serotonin and norepinephrine in mice lacking MAO A. Science, 268, 1763-1766.

Chen, W. J., Loh, E. W., Hsu, Y. P., Chen, C. C., Yu, J. M., \& Cheng, A. T. (1996). Alcohol-metabolizing genes and alcoholism among Taiwanese Han men: Independent effect of ADH2, ADH3 and ALDH2. British Journal of Psychiatry, 168, 762-767.

Clayton, R. R., Voss, H. L., Robbins, C., \& Skinner, W. F. (1986). Gender differences in drug use: An epidemiological perspective. In B. A. Ray \& M. C. Braude (Eds.), Women and drugs: A new era for research (DHHS Publication No. ADM 86-1447, National Institute on Drug Abuse Research Monograph 65, pp. 80-99). Rockville, MD: U.S. Department of Health and Human Services.

Clemente, I. C., Fananas, L., Moral, P., \& Sanchez-Turet, M. (1994). A study of the association of alcoholism with A1A2BO and MNSs polymorphisms. Alcohol and Alcoholism, 29, 711-714.

Cloninger, C. R. (1986). A unified biosocial theory of personality and its role in the development of anxiety states. Psychiatric Developments, 3, 167-226.

Cloninger, C. R. (1987a, April 24). Neurogenetic adaptive mechanisms in alcoholism. Science, 236, 410-416.

Cloninger, C. R. (1987b). A systematic method for clinical description and classification of personality variants. Archives of General Psychiatry, 44, 573-588. 
Cloninger, C., Bohman, M., \& Sigvardsson, S. (1981). Inheritance of alcohol abuse: Cross fostering analysis of adopted men. Archives of General Psychiatry, 38, 861-868.

Coccaro, E. F, Kavoussi, R. J., Sheline, Y. L, Lish, J. D., \& Csernansky, J. G. (1996). Impulsive aggression in personality disorder correlates with tritiated paroxetine binding in the platelet. Archives of General Psychiatry, 53, 531-536.

Comings, D. E., Muhleman, D., Dietz, G. W., Jr., \& Donlon, T. (1991). Human tryptophan oxygenase localized to 4q31: Possible implications for alcoholism and other behavioral disorders. Genomics, 9, 301-308.

Cotton, N. S. (1979). The familial incidence of alcoholism. A review. Journal of Studies on Alcohol, 40, 89-116.

Crabbe, J. C., Phillips, T. J., Feller, D. J., Hen, R., Wenger, C. D., Lessov, C. N., \& Schafer, G. L. (1996). Elevated alcohol consumption in null mutant mice lacking $5-\mathrm{HT}_{1 \mathrm{~B}}$ serotonin receptors. Nature Genetics, 14, 98-101.

Del Boca, F. K. (1994). Sex, gender, and alcoholic typologies. Annals of the New York Academy of Sciences, 708, 34-48.

Devor, E. J., \& Cloninger, C. R. (1989). Genetics of alcoholism. Annual Review of Genetics, 23, 19-36.

Donovan, J. E., \& Jessor, R. (1985). Structure of problem behavior in adolescence and young adulthood. Journal of Consulting and Clinical Psychology, 53, 890-904.

Doty, P., Zacny, J., \& deWit, H. (1994). The effects of ondonsetron pretreatment on acute responses to ethanol in social drinkers. Behavioral Pharmacology, 5, 461-469.

Ebstein, R. P., Segman, R., Benjamin, J., Osher, Y, Nemanov, L., \& Belmaker, R. H. (1997). 5-HT2C (HTR2C) serotonin receptor gene polymorphism associated with the human personality trait of reward dependence: Interaction with dopamine $\mathrm{D}_{4}$ receptor (D4DR) and dopamine $\mathrm{D}_{3}$ receptor (D3DR) polymorphisms. American Journal of Medical Genetics, 74, 65-72.

Edenberg, H. J., Foroud, T., Roller, D. L., Goate, A., Rice, J., Van Eerdewegh, P., Reich, T., Cloninger, C. R., Nurnberger, J. L, Kowalczuk, M., Wu, B., Li, T.-K., Conneally, P. M., Tischfield, J. A., Wu, W., Shears, S., Crowe, R., Hesselbrock, V, Schuckit, M., Porjesz, B., \& Begleiter, H. (1998). A family-based analysis of the association of the dopamine $\mathrm{D}_{2}$ receptor (DRD2) with alcoholism. Alcoholism: Clinical and Experimental Research, 22, 505-512.

Ernouf, D., Compagnon, P., Lothion, P., Narcisse, G., Bernard, J. Y, \& Daoust, M. (1993). Platelets 3H 5-HT uptake in descendants from alcoholic patients: A potential risk factor for alcohol dependence? Life Sciences, 52, 989-995.

Estevez, R, Parrillo, S., Giusti, M., \& Monti, J. M. (1995). Single-dose ritanserin and alcohol in healthy volunteers: A placebo-controlled trial. Alcohol, 12, 541-545.

Falk, C. T., \& Rubenstein, P. (1987). Haplotype relative risks: An easy reliable way to construct a proper control sample for risk calculations. Annals of Human Genetics, 51, 227-233.

Fillmore, K. M. (1984). “When angels fall . ..": Women's drinking as cultural preoccupation and as reality. In S. C. Wilsnack \& L. J. Beckman (Eds.), Alcohol problems in women: Antecedents, consequences, and intervention (pp. 7-36). New York: Guilford Press.

Fils-Aime, M.-L., Eckardt, M. J., George, D. T., Brown, G. L., Mefford, L, \& Linnoila, M. (1996). Earlyonset alcoholics have lower cerebrospinal fluid 5-hydroxyindoleacetic acid levels. Archives of General Psychiatry, 53, 211-216.

Fuller, R. K., Branchey, L., Brightwell, D. R., Derman, R. M., Emrick, C. D., Iber, F. L., James, K. E., Lacoursiere, R. B., Lee, K. K., Lowenstam, L, Maany, L, Neiderhiser, D., Nocks, J. J., \& Shaw, S. (1986). Disulfiram treatment of alcoholism: A Veterans Administration cooperative study. Journal of the American Medical Association, 256, 1449-1455. 
Gatto, G. J., Murphy, J. M., McBride, W. J., Lumeng, L., \& Li, T. K. (1990). Effects of fluoxetine and desipramine on palatability-induced ethanol consumption in the alcohol-nonpreferring (NP) line of rats. Alcohol, 7, 531-536.

Gelernter, J., Goldman, D., \& Risch, N. (1993). The A1 allele of the D2 dopamine receptor gene and alcoholism, a reappraisal. Journal of the American Medical Association, 269, 1673-1677.

George, D. T, Benkelfat, C., Rawlings, R. R., Eckardt, M. J., Phillips, M. J., Nutt, D. J., Wynne, D., Murphy, D. L., \& Linnoila, M. (1997). Behavioral and neuroendocrine responses to $m$-chloro-phenylpiperazine in subtypes of alcoholics and healthy comparison subjects. American Journal of Psychiatry, 154, 81-87.

George, D. T, Lindquist, T, Rawlings, R. R., Eckardt, M. J., Moss, H., Mathis, C., Martin, P. R., \& Linnoila, M. (1992). Pharmacologic maintenance of abstinence in patients with alcoholism: No efficacy of 5-hydroxytryptophan or levodopa. Clinical Pharmacology and Therapeutics, 52, 553-560.

Gerra, G., Caccavari, R., Delsignore, R., Bocchi, R., Fertonani, G., \& Passeri, M. (1992). Effects of fluoxetine and Ca-acetylhomotaurinate on alcohol intake in familial and nonfamilial alcoholic patients. Current Therapeutics Research, 52, 291-295.

Goldman, D. (1995). Identifying alcoholism vulnerability alleles. Alcoholism: Clinical and Experimental Research, 19, 824-829.

Goldman, D., Brown, G. L., Albaugh, B., Robin, R., Goodson, S., Trunzo, M., Akhtar, L., Lucas-Derse, S., Long, J., \& Linnoila, M. (1993). DRD2 dopamine receptor genotype, linkage disequilibrium and alcoholism in American Indians and other populations. Alcoholism: Clinical and Experimental Research, 17, 199-204.

Goldman, D., Dean, M., Brown, G. L., Bolos, A. M., Tokola, R., Virkkunen, M., \& Linnoila, M. (1992). $\mathrm{D}_{2}$ dopamine receptor genotype and cerebrospinal fluid homovanillic acid, 5-hydroxyindoleacetic acid and 3-methoxy-4-hydroxyphenylglycol in Finnish and American alcoholics. Acta Psychiatrica Scandinavica, 86, 351-357.

Goldman, D., Lappalainen, J., Ozaki, N., Nakhai, B., Bergen, A., Pesonen, U., Koulu, M., Long, J., Wang, C.-Y., Nielsen, D. A., Dean, M., Chang, L., Weight, F, Eggert, M., Virkkunen, M., \& Linnoila, M. (1995, June). Natural structural variants of four human serotonin receptors and relationship of 5HT2C to alcoholism. Paper presented at the meeting of the Research Society on Alcoholism, Colorado Springs, CO.

Goodwin, D. (1979). Alcoholism and heredity. Archives of General Psychiatry, 36, 57-61.

Gorelick, D. A. (1989). Serotonin uptake blockers and the treatment of alcoholism. Recent Developments in Alcoholism, 7, 267-281.

Graham, K. (1980). Theories of intoxicated aggression. Canadian Journal of Behavioral Science, 12, 141-151.

Guze, S., Cloninger, C. R., Martin, R., \& Clayton, P. J. (1986). Alcoholism as a medical disorder. Comprehensive Psychiatry, 27, 501-510.

Hallman, J., von Knorring, L., \& Oreland, L. (1996). Personality disorders according to DSM-III-R and thrombocyte monoamine oxidase activity in Type 1 and Type 2 alcoholics. Journal of Studies on Alcohol, 57, 155-161.

Hamblin, M. W., McGuffin, R. W, Metcalf, M. A., Dorsa, D. M., \& Merchant, K. M. (1992). Distinct 5-НТ 1 в and 5-HT1 serotonin receptors in rat: Structural and pharmacological comparison of the two cloned receptors. Molecular and Cellular Neurosciences, 3, 578-587.

Handelsman, L., Holloway, K., Kahn, R. S., Sturiano, C., Rinaldi, P. J., Bernstein, D. P., Siever, L., Gabriel, S., \& Cooper, T. B. (1996). Hostility is associated with low prolactin response to metachlorophenylpiperazine in abstinent alcoholics. Alcoholism: Clinical and Experimental Research, 20, 824-829. 
Harris, B. D., Kurth, J. H., Barnes, R. L, Bowcock, A. M., \& Kurth, M. C. (1993). Linkage analysis of the monoamine A and B genes using newly-defined polymorphisms. Cytogenetics and Cell Genetics, 62, 236-237.

Helzer, J. E., Burnam, A., \& McEvoy, L. T. (1991). Alcohol abuse and dependence. In L N. Robins \& D. A. Regier (Eds.), Psychiatric disorders in America: The epidemiologic catchment area studies. New York: Free Press.

Hesselbrock, M. N., Hesselbrock, V. M., Babor, T. R, Meyer, R. E., Stabenau, J. R., \& Weidenman, M. A. (1984). Antisocial behavior, psychopathology and problem drinking in the natural history of alcoholism. In D. W. Goodwin, K. T. Van Dusen, \& S. A. Mednick (Eds.), Longitudinal research on alcoholism (pp. 197-212). Boston: Kluwer-Nijhoff.

Hesselbrock, A. N., Meyer, R. E., \& Keener, S. J. (1985). Psychopathology in hospitalized alcoholics. Archives of General Psychiatry, 42, 1050-1055.

Higley, J. D., Mehlman, P. T, Higley, S. B., Fernald, B., Vickers, J., Lindell, S. G., Taub, D. M., Suomi, S. J., \& Linnoila, M. (1996). Excessive mortality in young free-ranging male nonhuman primates with low cerebrospinal fluid 5-hydroxyindoleacetic acid concentrations. Archives of General Psychiatry, 53, 537-543.

Higley, J. D., Suomi, S. J., \& Linnoila, M. (1996a). A nonhuman primate model of Type II excessive alcohol consumption? Part 1. Low cerebrospinal fluid 5-hydroxyindoleacetic acid concentrations and diminished social competence correlate with excessive alcohol consumption. Alcoholism: Clinical and Experimental Research, 20, 629-642.

Higley, J. D., Suomi, S. J., \& Linnoila, M. (1996b). A nonhuman primate model of Type II alcoholism? Part 2. Diminished social competence and excessive aggression correlates with low cerebrospinal fluid 5-hydroxyindoleacetic acid concentrations. Alcoholism: Clinical and Experimental Research, 20, 643-650.

Hill, E. M., Wilson, A. R, Elston, R. C., \& Winokur, G. (1988). Evidence for possible linkage between genetic markers and affective disorders. Biological Psychiatry, 24, 903-917.

Hill, S. Y, Aston, C., \& Rabin, B. (1988). Suggestive evidence of genetic linkage between alcoholism and the MNS blood group. Alcoholism: Clinical and Experimental Research, 12, 811-814.

Hoffman, B. J., Mezey, E., \& Brownstein, M. J. (1991, October 25). Cloning of a serotonin transporter affected by antidepressants. Science, 254, 579-580.

Hotamisligil, G. S., \& Breakefield, X. O. (1991). Human monoamine oxidase A gene determines levels of enzyme activity. American Journal of Human Genetics, 49, 383-392.

Hsieh, C. L., Bowcock, A. M., Fairer, L. A., Hebert, J. M., Huang, K. N., Cavalli-Sforza, L. L., Julius, D., \& Francke, U. (1990). The serotonin receptor subtype 2 locus HTR2 is on human chromosome 13 near genes for esterase D and retinoblastoma-1 and on mouse chromosome 14. Somatic Cell and Molecular Genetics, 16, 567-574.

Humphrey, P. P. A., Hartig, P., \& Hoyer, D. (1993). A proposed new nomenclature for 5-HT receptors. Trends in Pharmacological Sciences, 14, 233-236.

Hunt, W. A. (1993). Neuroscience research: How has it contributed to our understanding of alcohol abuse and alcoholism? A review. Alcohol: Clinical and Experimental Research, 17, 1055-1065.

Insel, T. R., Zohar, J., Benkelfat, C., \& Murphy, D. L. (1990). Serotonin in obsessions, compulsions, and the control of aggressive impulses. Annals of the New York Academy of Sciences, 600, 574-585.

Jacob, B. L., \& Fornal, C. A. (1994). Serotonin and behavior: A general hypothesis. In F. E. Bloom \& D. J. Kupfer (Eds.), Psychopharmacology: The fourth generation of progress (pp. 461-469). New York: Raven. 
Johnson, B. A., Campling, G. M., Griffiths, P., \& Cowen, P. J. (1993). Attenuation of some ethanolinduced mood changes and the desire to drink by 5-HT3 receptor blockade: A preliminary study in healthy male volunteers. Psychopharmacology, 112, 142-144.

Johnson, B. A., Jasinski, D. R., Galloway, G. P., Kranzler, H., Weinreib, R., Anton, R. F., Mason, B. J., Bohn, M. J., Pettinati, H. M., Rawson, R., \& Clyde, C. (1996). Ritanserin in the treatment of alcohol dependence-a multi-center clinical trial. Ritanserin Study Group. Psychopharmacology (Berl), 128, 206-215.

Johnson, E. O., van den Bree, M. B. M., \& Pickens, R. W. (1996a). Indicators of genetic and environmental influence in alcoholdependent individuals. Alcoholism: Clinical and Experimental Research, 20, 67-74.

Johnson, E. O., van den Bree, M. B. M., \& Pickens, R. W. (1996b). Subtypes of alcohol-dependent men: A typology based on relative genetic and environmental loading. Alcoholism: Clinical and Experimental Research, 20, 1472-1480.

Jones, M. C. (1971). Personality antecedents and correlates of drinking patterns in women. Journal of Consulting and Clinical Psychology, 36, 61-69.

Kabel, D. I., \& Petty, F. (1996). A placebo-controlled, double-blind study of fluoxetine in severe alcohol dependence: Adjunctive pharmacotherapy during and after inpatient treatment. Alcoholism: Clinical and Experimental Research, 20, 780-784.

Kaij, L. (1960). Alcoholism in twins. Stockholm: Almquist \& Wiksell.

Kendler, K. S., Heath, A. C., Neale, M. C., Kessler, R. C., \& Eaves, L. J. (1992). A population-based twin study of alcoholism in women. Journal of the American Medical Association, 268, 1877-1882.

Kendler, K. S., Heath, A. C., Neale, M. C., Kessel, R. C., \& Eaves, L. J. (1993). Alcoholism and major depression in women: A twin study of the causes of comorbidity. Archives of General Psychiatry, 50, 690-698.

Kendler, K. S., Neale, M. C., Heath, A. C., Kessler, R. C., \& Eaves, L. J. (1994). A twin-family study of alcoholism in women. American Journal of Psychiatry, 151, 707-715.

Keyes, R. C., Botchin, M. B., Kaplan, J. R., Manuck, S. B., \& Mann, J. J. (1995). Aggression and brain serotonergic responsivity: Response to slides in male macaques. Physiology and Behavior, 57, 205-208.

King, A. C., Volpicelli, J. R., Frazer, A., \& O’Brien, C. P. (1997). Effect of naltrexone on subjective response in subjects at high and low risk for future alcohol dependence. Psychopharmacology, 129, 15-22.

Kranzler, H. R., \& Anton, R. F. (1994). Implications of recent neuropsychopharmacologic research for understanding the etiology and development of alcoholism. Journal of Consulting and Clinical Psychology, 62, 1116-1126.

Kranzler, H. R., Burleson, J. A., Brown, J., \& Babor, T. F. (1996). Fluoxetine treatment seems to reduce the beneficial effects of cognitive-behavioral therapy in Type B alcoholics. Alcoholism: Clinical and Experimental Research, 20, 1534-1541.

Kranzler, H. R., Burleson, J. A., Del Boca, F. K., Babor, T. F, Korner, P., Brown, J., \& Bohn, M. J. (1994). Buspirone treatment of anxious alcoholics: A placebo-controlled trial. Archives of General Psychiatry, 51, 720-731.

Kranzler, H. R., Burleson, J. A., Korner, P., Del Boca, F. K., Bohn, M. J., Brown, J., \& Liebowitz, N. (1995). Placebo-controlled trial of fluoxetine as an adjunct to relapse prevention in alcoholics. American Journal of Psychiatry, 51, 898-911.

Krystal, J. H., Webb, E., Cooney, N., Kranzler, H. R., \& Charney, D. S. (1994). Specificity of ethanollike effects elicited by serotonergic and noradrenergic mechanisms. Archives of General Psychiatry, 51, 898-911. 
Krystal, J. H., Webb, E., Cooney, N., Kranzler, H. R., Southwick, S. W., Heninger, G. R., \& Charney, D. S. (1996). Serotonergic and noradrenergic dysregulation in alcoholism: $m$-chlorophenylpiperazine and yohimbine effects in recently detoxified alcoholics and healthy comparison subjects. American Journal of Psychiatry, 153, 83-92.

Kushner, M. G., Sher, K. J., \& Beitman, B. D. (1990). The relation between alcohol problems and the anxiety disorders. American Journal of Psychiatry, 147, 685-695.

Lander, E. S., \& Schork, N. J. (1994, September 30). Genetic dissection of complex traits. Science, 265 , 2037-2048.

Lappalainen, J., Dean, M., Charbonneau, L., Virkkunen, M., Linnoila, M., \& Goldman, D. (1995). Mapping of the serotonin 5-HTiD $\beta$ autoreceptor gene on chromosome 6 and direct analysis for sequence variants. American Journal of Medical Genetics, 60, 157-161.

Lappalainen, J., Long, J. C., Eggert, M., Ozaki, N., Robin, R. W, Brown, G. L., Naukkarinen, H., Virkkunen, M., Linnoila, M., \& Goldman, D. (1998). Linkage of antisocial alcoholism to the serotonin 5-HT1B receptor gene in 2 populations. Archives of General Psychiatry, 55, 989-994.

Lappalainen, J., Zhang, L., Dean, M., Oz, M., Ozaki, N., Yu, D.-H., Virkkunen, M., Weight, F., Linnoila, M., \& Goldman, D. (1995). Identification, expression, and pharmacology of a Cys23-Ser23 substitution in the human 5-HT2C receptor gene (HTR2C). Genomics, 27, 274-279.

Lê, A. D., Tomkins, D. M., \& Sellers, E. M. (1996). Use of serotonin (5-HT) and opiate-based drugs in the pharmacotherapy of alcohol dependence: An overview of the preclinical data. Alcohol and Alcoholism, 37 (Suppl. 1), 27-32.

Lee, M. A., \& Meltzer, H. Y. (1991). Neuroendocrine responses to serotonergic agents in alcoholics. Biological Psychiatry, 30, 1017-1030.

LeMarquand, D., Pihl, R. O., \& Benkelfat, C. (1994a). Serotonin and alcohol intake, abuse, and dependence: Clinical evidence. Biological Psychiatry, 36, 326-337.

LeMarquand, D., Pihl, R. O., \& Benkelfat, C. (1994b). Serotonin and alcohol intake, abuse, and dependence: Findings of animal studies. Biological Psychiatry, 36, 395-421.

Lenders, J. W. M., Eisenhofer, G., Abeling, N. G. G. M., Berger, W., Murphy, D. L., Konings, C. H., Wagemakers, L. M. B., Kopin, I. J., Karoum, F., van Gennip, A. H., \& Brunner, H. G. (1997). Specific deficiencies of the $\mathrm{A}$ and $\mathrm{B}$ isoenzymes of monoamine oxidase are characterized by distinct neurochemical and clinical phenotypes. Jounal of Clinical Investigation. 97, 1010-1019.

Lesch, K.-P., Bengel, D., Heils, A., Sabol, S. Z., Greenberg, B. D., Petri, S., Benjamin, J., Muller, C. R., Hamer, D. H., \& Murphy, D. L. (1996, November 29). Association of anxiety-related traits with a polymorphism in the serotonin transporter gene regulatory region. Science, 274, 1527-1531.

Lex, B. W., Goldberg, M. E., Mendelson, J. H., Lawler, N. S., \& Bower, T. (1994). Components of antisocial personality disorder among women convicted for drunk driving. Annals of the New York Academy of Sciences, 708, 49-58.

Limson, R., Goldman, D., Roy, A., Lamparski, D., Ravitz, B., Adinoff, B., \& Linnoila, M. (1991). Personality and cerebrospinal fluid monoamine metabolites in alcoholics and controls. Archives of General Psychiatry, 48, 437-441.

Litt, M. D., Babor, T. F., Del Boca, F. K., Kadden, R. M., \& Cooney, N. L. (1992). Types of alcoholics, II. Application of an empirically derived typology to treatment matching. Archives of General Psychiatry, 49, 609-614.

Litten, R. Z., Allen, J., \& Fertig, J. (1996). Pharmacotherapies for alcohol problems: A review of research with focus on developments since 1991. Alcoholism: Clinical and Experimental Research, 20, 859-876. 
Littrell, J. (1988). The Swedish studies of the adopted children of alcoholics. Journal of Studies on Alcohol, 49, 491-499.

Long, J. C., Knowler, W. C., Hanson, R. L., Robin, R. W., Urbanek, M., Moore, E., Bennett, P. H., \& Goldman, D. (1998). Evidence for genetic linkage to alcohol dependence on chromosomes 4 and 11 from an autosome-wide scan in an American Indian population. American Journal of Medical Genetics, 81, 216-221.

Lykouras, E., Markianos, M., \& Moussas, G. (1989). Platelet monoamine oxidase, plasma dopamine beta-hydroxylase activity, dementia and family history of alcoholism in chronic alcoholics. Acta Psychiatric Scandinavica, 80, 487-491.

Malcolm, R., Anton, R. F., Randall, C. L., Johnston, A., Brady, K., \& Thevos, A. (1992). A placebocontrolled trial of buspirone in anxious inpatient alcoholics. Alcoholism: Clinical and Experimental Research, 16, 1007-1013.

McBride, W. J., Bodart, L., Lumeng, L., \& Li, T.-K. (1995). Association between low contents of dopamine and serotonin in the nucleus accumbens and high alcohol preference. Alcoholism: Clinical and Experimental Research, 19, 1420-1422.

McBride, W. J., Chernet, E., Rabold, J. A., Lumeng, L., \& Li, T.-K. (1993). Serotonin-2 receptors in the CNS of alcohol-preferring and -nonpreferring rats. Pharmacology Biochemistry and Behavior, 46, 631-636.

McBride, W. J., Guan, X. M., Chernet, E., Lumeng, L., \& Li, T.-K. (1994). Regional serotonin 1A receptors in the CNS of alcohol-preferring and -nonpreferring rats. Pharmacology Biochemistry and Behavior, 49, 7-12.

McGinnis, R. E., Ewens, W. J., \& Spielman, R. S. (1995). The TDT reveals linkage and linkage disequilibrium in a rare disease. Genetic Epidemiology, 12, 637-640.

McGue, M. (1994). Genes, environment, and the etiology of alcoholism. In R. A. Zucker, G. Boyd, \& J. Howard (Eds.), The Development of Alcohol Problems: Exploring the Biopsychosocial Matrix of Risk (National Institute on Alcohol Abuse and Alcoholism Research Monograph No. 26, pp. 1-40). Rockville, MD: U.S. Department of Health and Human Services.

McGue, M., Pickens, R. W., \& Svikis, D. S. (1992). Sex and age effects on the inheritance of alcohol problems: A twin study. Journal of Abnormal Psychology, 101, 3-17.

McGuffin, P., Owen, M. J., O’Donovan, M. C., Thapar, A., \& Gottesman, I. I. (1994). Seminars in psychiatric genetics. London: Royal College of Psychiatrists/Gaskell.

Mehlman, P. T., Higley, J. D., Faucher, I., Lilly, A. A., Taub, D. M., Vickers, J., Suomi, S. J., \& Linnoila, M. (1994). Low CSF 5-HI A A concentrations and severe aggression and impaired impulse control in nonhuman primates. American Journal of Psychiatry, 151, 1485-1491.

Meltzer, H. Y., \& Arora, R. C. (1988). Genetic control of serotonin uptake in blood platelets: A twin study. Psychiatry Research, 24, 263-270.

Merikangas, K. R. (1990). The genetic epidemiology of alcoholism. Psychological Medicine, 20, 11-22.

Merikangas, K. R., Leckman, J. F, Prusoff, B. A., Pauls, D. L., \& Weissman, M. M. (1985). Familial transmission of depression and alcoholism. Archives of General Psychiatry, 42, 367-372.

Meyer, R. E. (1994). Toward a comprehensive theory of alcoholism. Annals of the New York Academy of Sciences, 708, 238-250.

Monti, J. M., \& Alterwain, P. (1991). Ritanserin decreases alcohol intake in chronic alcoholics. Lancet, 337,60 .

Moss, H. B., Yao, J. K., \& Panzak, G. L. (1990). Serotonergic responsivity and behavioral dimensions in antisocial personality disorder with substance abuse. Biological Psychiatry, 28, 325-338. 
Murphy, D. L. (1990). Neuropsychiatric disorders and the multiple human brain serotonin receptor subtypes and subsystems. Neuropsychopharmacology, 3, 457-471.

Murphy, D. L., Mueller, E. A., Garrick, N. A., \& Aulakh, C. S. (1986). Use of serotonergic agents in the clinical assessment of central serotonin function. Journal of Clinical Psychiatry, 47 (Suppl.), 9-15.

Murphy, J. M., McBride, W. J., Lumeng, L., \& Li, T.-K. (1982). Regional brain levels of monoamines in alcohol-preferring and -nonpreferring lines of rats. Pharmacology Biochemistry and Behavior, 16, 145-149.

Murphy, J. M., Waller, M. B., Gatto, G. J., McBride, W. J., Lumeng, L., \& Li, T.-K. (1988). Effects of fluoxetine on the intragastric self-administration of ethanol in the alcohol preferring $\mathrm{P}$ line of rats. Alcohol, 5, 283-286.

Naranjo, C. A., \& Bremner, K. E. (1993). Clinical pharmacology of serotonin-altering medications for decreasing alcohol consumption. Alcohol and Alcoholism, 2, 221-229.

Naranjo, C. A., Bremner, K. E., \& Lanctot, K. L. (1995). Effects of citalopram and a brief psycho-social intervention on alcohol intake, dependence and problems. Addiction, 90, 87-99.

Naranjo, C. A., Poulos, C. X., Lanctot, K. L., Bremner, K. E., Kwok, M., \& Umana, M. (1995). Ritanserin, a central 5- $\mathrm{HT}_{2}$ antagonist, in heavy social drinkers: Desire to drink, alcohol intake and related effects. Addiction, 90, 893-905.

Naranjo, C. A., \& Sellers, E. M. (1989). Serotonin uptake inhibitors attenuate ethanol intake in problem drinkers. Recent Developments in Alcoholism, 7, 255-266.

Naranjo, C. A., Sellers, E. M., Sullivan, J. T., Woodley, D. V., Kadlec, K., \& Sykora, K. (1987). Serotonin uptake inhibitor citalopram attenuates ethanol intake. Clinical Pharmacology and Therapeutics, 41, 266-274.

Nielsen, D. A., Dean, M., \& Goldman, D. (1992). Genetic mapping of the human tryptophan hydroxylase gene on chromosome 11, using an intronic conformational polymorphism. American Journal of Human Genetics, 51, 1366-1371.

Nielsen, D. A., Goldman, D., Virkkunen, M., Tokola, R., Rawlings, R., \& Linnoila, M. (1994). Suicidality and 5-hydroxyindoleacetic acid concentration associated with a tryptophan hydroxylase polymorphism. Archives of General Psychiatry, 51, 34-38.

Nunes, E., Quitkin, F., \& Berman, C. (1988). Panic disorder and depression in female alcoholics. Journal of Clinical Psychiatry, 49, 441-443.

O'Malley, S. S., Jaffe, A. J., Chang, G., Schottenfeld, R. S., Meyer, R. E., \& Rounsaville, G. (1992). Naltrexone and coping skills therapy for alcohol dependence. Archives in General Psychiatry, 49, 881-887.

Panocka, I., Ciccocioppo, R., Polidori, C., Pompei, P., \& Massi, M. (1995). The 5-HT4 receptor antagonist, GR113808, reduces ethanol intake in alcohol-preferring rats. Pharmacology Biochemistry and Behavior, 52, 255-259.

Pato, C. N., Macciardi, P., Pato, M. T., Verga, M., \& Kennedy, J. L. (1993). Review of the putative association of dopamine $\mathrm{D}_{2}$ receptor and alcoholism: A meta-analysis. American Journal of Medical Genetics, 48, 78-82.

Pettinati, H. M. (1996). Use of serotonin selective pharmacotherapy in the treatment of alcohol dependence. Alcoholism: Clinical and Experimental Research, 20, 23 A-29A.

Phillips, T. J., Crabbe, J. C., Metten, P., \& Belknap, J. K. (1994). Localization of genes affecting alcohol drinking in mice. Alcoholism: Clinical and Experimental Research, 18, 931-951.

Pickens, R. W., Svikis, D. S., McGue, M., Lykken, D. T., Heston, L. L., \& Clayton, P. J. (1991). Heterogeneity in the inheritance of alcoholism: A study of male and female twins. Archives of General Psychiatry, 48, 19-28. 
Pihl, R. O., Peterson, J. B., \& Lau, M. A. (1993). A biosocial model of the alcohol-aggression relationship. Journal of Studies on Alcohol (Suppl. 11), 128-139.

Popkin, C. L., Kannenberg, C. H., Lacey, J. H., \& Waller, P. F. (1988). Assessment of classification instruments designed to detect alcohol abuse. Final report (National Highway Traffic Safety Administration Report No. DOT/HS 807 475). Chapel Hill, NC: Highway Safety Research Center.

Prescott, C. A., Hewitt, J. K., Heath, A. C., Truett, K. R., Neale, M. C., \& Eaves, L. J. (1994). Environmental and genetic influences on alcohol use in a volunteer sample of older twins. Journal of Studies on Alcohol, 55, 18-33.

Prescott, C. A., Hewitt, J. K., Truett, K. R., Heath, A. C., Neale, M. C., \& Eaves, L. J. (1994). Genetic and environmental influences on lifetime alcohol-related problems in a volunteer sample of older twins. Journal of Studies on Alcohol, 55, 184-202.

Reich, T., \& Cloninger, C. R. (1990). Time-dependent model of the familial transmission of alcoholism. In C. R. Cloninger \& H. Begleiter (Eds.), Genetics and biology of alcoholism (pp. 55-73). Cold Springs Harbor, NY: Cold Springs Harbor Laboratory Press.

Reich, T., Edenberg, H. J., Goate, A., Williams, J. P., Rice, J. T, Van Eerdewegh, P., Foroud, T., Hesselbrock, V., Schuckit, M. A., Bucholz, K., Porjesz, B., Li, T.-K., Conneally, P. M., Nurnberger, J. I., Jr., Tischfield, J. A., Crowe, R. R., Cloninger, C. R., Wu, W., Shears, S., Carr, K., Crose, C., Willig, C., \& Begleiter, H. (1998). Genome-wide search for genes affecting the risk for alcohol dependence. American Journal of Medical Genetics, 81, 207-215.

Rezvani, A. H., Overstreet, D. H., \& Janowsky, D. S. (1990). Genetic serotonin deficiency and alcohol preference in the fawn hooded rats. Alcohol and Alcoholism, 25, 573-575.

Roth, B. L. (1994). Multiple serotonin receptors: Clinical and experimental aspects. Annals of Clinical Psychiatry, 6, 67-78.

Roy, A., Lamparski, D., De Jong, J., Adinoff, B., Ravitz, B., George, D. T., Nutt, D., \& Linnoila, M. (1990). Cerebrospinal fluid monoamine metabolites in alcoholic patients who attempted suicide. Acta Psychiatrica Scandinavica, 81, 58-61.

Roy, A., \& Linnoila, M. (1989). CSF studies on alcoholism and related behaviors. Progress in Neuropsychopharmacology and Biological Psychiatry, 13, 505-511.

Roy, A., Virkkunen, M., \& Linnoila, M. (1987). Reduced central serotonin turnover in a subgroup of alcoholics? Progress in Neuropsychopharmacology and Biological Psychiatry, 11, 173-177.

Rubenstein, P., Walker, M., Carpenter, C., Carrier, C., Krassner, J., Falk, C., \& Ginsberg, F. (1981). Genetics of HLA disease associations. Human Immunology, 3, 384.

Sanchez, C., Arnt, J., Hyttel, J., \& Moltzen, E. K. (1993). The role of serotonergic mechanisms in inhibition of isolation-induced aggression in male mice. Psychopharmacology, 110, 53-59.

Sander, T., Harms, H., Lesch, K.-P, Dufeu, P., Kuhn, S., Hoehe, M., Rommelspacher, H., \& Schmidt, L. G. (1997) Association analysis of a regulatory variation of the serotonin transporter gene with severe alcohol dependence. Alcoholism: Clinical and Experimental Research, 21, 1356-1359.

Same, Y., Mandel, J., Goncalves, M. H., Brook, S., Garni, M., \& Elizur, A. (1995). Imipramine binding to blood platelets and aggressive behavior in offenders, schizophrenics and normal volunteers. Neuropsychobiology, 31, 120-124.

Saudou, F., Amara, D. A., Dierich, A., LeMeur, M., Ramboz, S., Segu, L., Buhot, M. C., \& Hen, R. (1994, September 23). Enhanced aggressive behavior in mice lacking 5-НТ1в receptor. Science, 265, 1875-1878.

Schuckit, M. A. (1980). Self-rating of alcohol intoxication by young men with and without family histories of alcoholism. Journal of Studies on Alcohol, 41, 242-249. 
Schuckit, M. A. (1994). Low level of response to alcohol as a predictor of future alcoholism. American Journal of Psychiatry, 151, 184-189.

Schuckit, M. A. (1996). Recent developments in the pharmacotherapy of alcohol dependence. Journal of Consulting and Clinical Psychology, 64, 669-676.

Schuckit, M. A., \& Hesselbrock, V. (1994). Alcohol dependence and anxiety disorders: What is the relationship? American Journal of Psychiatry, 151, 1723-1734.

Schuckit, M. A., Pitts, F. N., Reich, T, King, L., \& Winokur, G. (1969). Alcoholism: Two types of alcoholism in women. Archives of General Psychiatry, 20, 301-306.

Searles, J. S. (1988). The role of genetics in the pathogenesis of alcoholism. Journal of Abnormal Psychology, 97, 153-167.

Searles, J. S., \& Alterman, A. I. (1994). Environmental differences in young men with and without a family history of alcoholism. Annals of the New York Academy of Sciences, 708, 147-156.

Sellers, E. M., Toneatto, T., Romach, M. K., Somer, G. R., Sobell, L. C., \& Sobell, M. B. (1994). Clinical efficacy of the 5-HT3 antagonist ondanetron in alcohol abuse and dependence. Alcoholism: Clinical and Experimental Research, 18, 879-885.

Sher, K. J. (1991). Children of alcoholics: A critical appraisal of theory and research. Chicago: University of Chicago Press.

Sher, K. J. (1994). Individual-level risk factors. In R. A. Zucker, G. Boyd, \& J. Howard (Eds.), The development of alcohol problems: Exploring the biopsychosocial matrix of risk (National Institute on Alcohol Abuse and Alcoholism Research Monograph No. 26, pp. 77-108). Rockville, MD: U.S. Department of Health and Human Services.

Sherif, F., Hallman, J., \& Oreland, L. (1992). Low platelet gamma-aminobutyrate aminotransferase and monoamine oxidase activities in chronic alcoholic patients. Alcoholism: Clinical and Experimental Research, 16, 1014-1020.

Siever, L., \& Trestman, R. L. (1993). The serotonin system and aggressive personality disorder. International Clinical Psychopharmacology, 8, 33-39.

Sparkes, R. S., Lan, N., Klisak, I., Mohandas, T., Diep, A., Kojis, T., Heinzmann, C., \& Shih, J. C. (1991). Assignment of a serotonin 5HT-2 receptor gene (HTR2) to human chromosome 13q14-q21 and mouse chromosome 14. Genomics, 9, 461-465.

Spielman, R. S., McGinnis, R. E., \& Ewens, W. J. (1993). Transmission test for linkage disequilibrium: The insulin gene region and insulin-dependent diabetes mellitus (IDDM). American Journal of Human Genetics, 52, 506-516.

Stoll, J., \& Goldman, D. (1991). Isolation and structural characterization of the murine tryptophan hydroxylase gene. Journal of Neuroscience Research, 28, 457-465.

Stone, W. S., \& Gottesman, I. I. (1993). A perspective on the search for the causes of alcoholism: Slow down the rush to genetical judgements. Neurology, Psychiatry, and Brain Research, 1, 123-132.

Sullivan, J. L., Stanfield, C. N., Schanberg, S., \& Cavenar, J. (1978). Platelet monoamine oxidase and serum dopamine-betahydroxylase activity in chronic alcoholics. Archives of General Psychiatry, 35, 1209-1212.

Swift, R. M, Davidson, D., Whelihan, W., \& Kuznetsov, O. (1996). Ondansetron alters human alcohol intoxication. Biological Psychiatry, 40, 514-521.

Tabakoff, B., Hoffman, P. L., Lee, J. M., Saito, T., Willard, B., \& De Leon-Jones, F. (1988). Differences in platelet enzyme activity between alcoholics and nonalcoholics. New England Journal of Medicine, 318, 134-139. 
Tanna, V. L., Wilson, A. F., Winokur, G., \& Elston, R. C. (1988). Possible linkage between alcoholism and esterase-D. Journal of Studies on Alcohol, 49, 472-476.

Tarter, R. E., Alterman, A. E., \& Edwards, K. L. (1985). Vulnerability to alcoholism in men: A behaviorgenetic perspective. Journal of Studies on Alcohol, 46, 329-356.

Tiihonen, J., Ryynanen, O. P., Kauhanen, J., Hakola, H. P., \& Salaspuro, M. (1996). Citalopram in the treatment of alcoholism: A double-blind placebo-controlled study. Pharmacopsychiatry, 29, 27-29.

Tollefson, G. D., Montague-Clouse, J., \& Tollefson, S. L. (1992). Treatment of comorbid generalized anxiety in a recently detoxified alcoholic population with a selective serotonergic drug (buspirone). Journal of Clinical Psychopharmacology, 12, 19-26.

Vanyukov, M. M., Moss, H. B., Yu, L. M., Tarter, R. E., \& Deka, R. (1995). Preliminary evidence for an association of a dimicleotide repeat polymorphism at the MAOA gene with early onset alcoholism/substance abuse. American Journal of Medical Genetics, 60, 122-126.

Virkkunen, M., Eggert, M., Rawlings, R., \& Linnoila, M. (1996). A prospective follow-up study of alcoholic violent offenders and fire setters. Archives of General Psychiatry, 53, 523-529.

Virkkunen, M., \& Linnoila, M. (1993). Brain serotonin, Type II alcoholism and impulsive violence. Journal of Studies on Alcohol, 11, (Suppl.), 163-169.

Virkkunen, M., Rawlings, R., Tokola, R., Poland, R. E., Guidotti, A., Nemeroff, C., Bissette, G., Kalogeras, K., Karonen, S. L., \& Linnoila, M. (1994). CSF biochemistries, glucose metabolism, and diurnal activity rhythms in alcoholic, violent offenders, fire setters, and healthy volunteers. Archives of General Psychiatry, 51, 20-27.

Volpicelli, J. R., Alterman, A. I., Hayashida, M., \& O’Brien, C. P. (1992). Naltrexone in the treatment of alcohol dependence. Archives of General Psychiatry, 49, 876-880.

von Knorring, A.-L., Bohman, M., von Knorring, L., \& Oreland, L. (1985). Platelet MAO activity as a biological marker in subgroups of alcoholism. Acta Psychiatrica Scandinavica, 72, 51-58.

Warren, J. T., Jr., Peacock, M. L., \& Fink, J. K. (1992). An Rsal polymorphism in the human serotonin receptor gene (HTR1A): Detection by DGGE and RFLP analysis. Human Molecular Genetics, 1, 778.

Weber, M. D., Graham, J. W., Hansen, W. B., Flay, B. R., \& Johnson, C. A. (1989). Evidence for two paths of alcohol use onset in adolescents. Addictive Behaviors, 14, 399-408.

Weiss, B., Mertz, A., Schrock, E., Koenen, M., \& Rappold, G. (1995). Assignment of a human homolog of the mouse HTR3 receptor gene to chromosome 11q23.1-q23.2. Genomics, 29, 304-305.

Wesner, R. B., Tanna, V. L., Palmer, P. J., Thompson, R. J., Crowe, R. R., \& Winokur, G. (1991). Close linkage of esterase-D to unipolar depression and alcoholism is ruled out in eight pedigrees. Journal of Studies on Alcohol, 52, 609-612.

Whitworth, A. B., Fischer, F., Lesch, O. M., Nimmerichter, A., Oberbauer, H., Platz, T., Potgieter, A., Walter, H., \& Fleischhacker, W. W. (1996). Comparison of acamprosate and placebo in long-term treatment of alcohol dependence. Lancet, 347, 1438-1442.

Wieberg, A., Gottfries, C. G., \& Oreland, L. (1977). Low platelet monoamine oxidase activity in human alcoholics. Medical Biology, 55, 181-186.

Wong, D. T., Reid, L. R., Li, T.-K., \& Lumeng, L. (1993). Greater abundance of serotonin 1 A receptor in some brain areas of alcohol-preferring $(\mathrm{P})$ rats compared to nonpreferring (NP) rats. Pharmacology Biochemistry and Behavior, 46, 173-177.

Wong, D. T., Threlkeld, P. G., Lumeng, L., \& Li, T.-K. (1990). Higher density of serotonin-1A receptors in the hippocampus and cerebral cortex of alcohol-preferring P rats. Life Sciences, 46, 231-235. 
Zhou, F. C., McKinzie, D. L., Patel, T. D., Lumeng, L., \& Li, T.-K. (1998). Additive reduction of alcohol

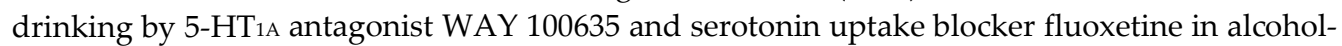
preferring P rats. Alcoholism: Clinical and Experimental Research, 22, 266-269.

Zucker, R. A. (1987). The four alcoholisms: A developmental account of the etiologic process. In P. C. Rivers (Ed.), Nebraska Symposium on Motivation. Alcohol and Addictive Behaviors (Vol. 34, pp. 2783). Lincoln, NE: University of Nebraska Press.

Zucker, R. A. (1994). Pathways to alcohol problems and alcoholism: A developmental account of the evidence for multiple alcoholisms and for contextual contributions to risk. In R. A. Zucker, G. Boyd, \& J. Howard (Eds.), The development of alcohol problems: Exploring the biopsychosocial matrix of risk (National Institute on Alcohol Abuse and Alcoholism Research Monograph No. 26, pp. 255-289). Rockville, MD: U.S. Department of Health and Human Services.

Zucker, R. A., Ellis, D. A., \& Fitzgerald, H. E. (1994). Developmental evidence for at least two alcoholisms. I. Biopsychosocial variation among pathways into symptomatic difficulty. Annals of the New York Academy of Sciences, 708, 134-146.

Zucker, R. A., Ellis, D. A., Fitzgerald, H. E., \& Bingham, C. R. (1996). Other evidence for at least two alcoholisms II: Life course variation in antisociality and heterogeneity of alcoholic outcome. Development and Psychopatholagy, 8, 831-848.

Zucker, R. A., \& Gomberg, E. S. L. (1995). Alcoholism and antisocial comorbidity in women: A note on a hot spot and some hypotheses. Manuscript submitted for publication. 